Estuarine, Coastal and Shelf Science

October 2016, Volume 180, Pages 190-203

http://dx.doi.org/10.1016/i.ecss.2016.06.029

http://archimer.ifremer.fr/doc/00346/45701/

(c) 2016 Elsevier Ltd. All rights reserved.

\title{
First steps of ecological restoration in Mediterranean lagoons: Shifts in phytoplankton communities
}

\author{
Leruste A. ${ }^{1}$, Malet Nathalie ${ }^{2}$, Munaron Dominique ${ }^{3}$, Derolez Valerie ${ }^{3}$, Hatey E. ${ }^{1}$, Collos Y. ${ }^{1}$, \\ De Wit R. ${ }^{1}$, Bec B. ${ }^{1,{ }^{*}}$
}

${ }^{1}$ UMR MARBEC, IRD, Ifremer, Université de Montpellier, CNRS, Bât. 24 - CC 093, Place Eugène Bataillon, 34095, Montpellier Cedex 5, France

2 Ifremer, LEPAC-Corse, ZI Furiani, Im Agostini, 20600, Bastia, France

${ }^{3}$ UMR MARBEC, IRD, Ifremer, Université de Montpellier, CNRS, LER-LR, BP 171, Avenue Jean

Monnet, 34203, Sète Cedex, France

* Corresponding author : Béatrice Bec, email address : Beatrice.Bec@umontpellier.fr

\begin{abstract}
:
Along the French Mediterranean coast, a complex of eight lagoons underwent intensive eutrophication over four decades, mainly related to nutrient over-enrichment from continuous sewage discharges. The lagoon complex displayed a wide trophic gradient from mesotrophy to hypertrophy and primary production was dominated by phytoplankton communities. In 2005, the implementation of an $11 \mathrm{~km}$ offshore outfall system diverted the treated sewage effluents leading to a drastic reduction of anthropogenic inputs of nitrogen and phosphorus into the lagoons. Time series data have been examined from 2000 to 2013 for physical, chemical and biological (phytoplankton) variables of the water column during the summer period. Since 2006, total nitrogen and phosphorus concentrations as well as chlorophyll biomass strongly decreased revealing an improvement in lagoon water quality. In summertime, the decline in phytoplankton biomass was accompanied by shifts in community structure and composition that could be explained by adopting a functional approach by considering the common functional traits of the main algal groups. These phytoplankton communities were dominated by functional groups of small-sized and fast-growing algae (diatoms, cryptophytes and green algae). The trajectories of summer phytoplankton communities displayed a complex response to changing nutrient loads over time. While diatoms were the major group in 2006 in all the lagoons, the summer phytoplankton composition in hypertrophic lagoons has shifted towards green algae, which are particularly well adapted to summertime conditions. All lagoons showed increasing proportion and occurrence of peridinin-rich dinophytes over time, probably related to their capacity for mixotrophy. The diversity patterns were marked by a strong variability in eutrophic and hypertrophic lagoons whereas phytoplankton community structure reached the highest diversity and stability in mesotrophic lagoons. We observe that during the re-oligotrophication process in coastal lagoons, phytoplankton shows complex trajectories with similarities with those observed in freshwater lake systems.
\end{abstract}

Keywords : Phytoplankton, Coastal lagoons, Nutrient, Sewage effluents, Re-oligotrophication 


\section{Introduction}

43 Eutrophication has been defined as a suite of adverse symptoms resulting from the nutrient and organic inputs (De Jonge and Elliott, 2011). High biomass decreases light availability, favoring among the primary producers the community that is most competitive for light, i.e., phytoplankton at the expense of macrophytes (Cebrian et al., 2014). This over-production causes a loss of diversity (Schramm, 1999; de Jonge and de Jong, 2002), habitat destruction and mortalities due to anoxia (Smith, 2006; Carlier et al., 2008). These phenomena negatively impact ecosystem health, result in increased vulnerability to disturbances (Heemsbergen et al., 2004; Worm and Lotze, 2006) and loss of ecosystem services (Bullock et al., 2011). In coastal areas, which are characterized by strong demographic growth, eutrophication has become a serious threat since the 1950s (Nixon, 1995). Coastal lagoons are particularly sensitive to eutrophication, since these systems tend to concentrate anthropogenic nutrient inputs (Knopper, 1994; Cloern, 2001; Kennish and Paerl, 2010) due to restricted exchanges with the sea and long water residence time (Boesch, 2002; Kennish and Paerl, 2010; Glibert et al., 2011).

In 2000, The Water Framework Directive (WFD) was established in Europe requiring member states to monitor the ecological and chemical quality state of water bodies and implement ways to achieve good status by 2021 (Sherrard et al., 2006; Cartaxana et al., 2009). Efforts have been made in many parts of the world to combat eutrophication by reducing nutrient inputs from watersheds and initiate ecological restoration. Ecological restoration is well documented in lakes which have been subjected to water quality improvement programs since the 70s (Jeppesen et al., 2005; 2007). Studies on lake restoration have shown that the response trajectories during re-oligotrophication are not simply the inverse of the previous eutrophication processes and are characterized by hysteresis. Accordingly, the recovery of ecosystem functions often lagged behind the reduction of 
external nutrient loadings, due to nutrient regeneration from sediments or the persistence of turbid alternative states because of dense blooms of phytoplankton or the presence of a pool of easily resuspendable organic matter (Scheffer et al., 1993; Scheffer and Carpenter, 2003; Sondergaard et al., 2003; Ibelings et al., 2007). Because of these phenomena, reoligotrophication processes are difficult to understand and predict for degraded systems (Van Donk et al., 2008). Hence, ecological restoration generally takes much longer than water degradation due to eutrophication. At first, it results in modifications of the composition and structure of primary producers communities. Phytoplankton is generally the first autotrophic compartment responding to the change of nutrient availability and other anthropogenic pressures (Livingston, 2000; Paerl et al., 2003). In restored lakes, this response has resulted in considerable changes of phytoplankton biomass, community structure and functional diversity (Ruggiu et al., 1998, Anneville and Pelletier, 2000; Katsiapi et al., 2013).

A functional approach to phytoplankton ecology appears particularly useful to study the adaptive responses of phytoplankton communities to re-oligotrophication. This approach is based on defining the functional traits of species that impact on their performance and survival (Violle et al., 2007) and, thus provides a better understanding of how phytoplankton communities respond to environmental changes. The functional approach has been used to understand how environmental changes or gradients drive phytoplankton community structure (Litchman et al., 2010). Some morphological and physiological traits particularly reflect the phytoplankton adaptations to nutrient availability, such as cell size, maximum growth rate and trophic regime (Litchman and Klausmeier, 2008; Litchman et al., 2010). During reoligotrophication, the reduction of nutrient inputs could thus favor small cells, which compete more effectively for nutrient uptake and show high growth rates (Chisholm, 1992; Kamenir and Morabito, 2009; Litchman et al., 2010), and mixotrophic species that present some 
114 In the South of France, to improve the ecological quality of eight eutrophied coastal lagoons 115 advantages over strictly autotrophic cells (Anneville and Pelletier, 2000). These functional traits highlight phytoplankton adaptations to the reduction of nutrient availability and represent an interesting tool to evaluate the impact of changing eutrophication status.

Since the implementation of the WFD, coastal waters represent a major issue for management and ecological restoration which has been used to reestablish ecosystems services. So far, little is known about the responses of coastal ecosystems to ecological restoration (Vidal et al., 1999; Duarte et al., 2009; Nixon, 2009). The recent literature describes a diversity of responses to restoration (Boesch, 2002; Elliott et al., 2007; Ho et al., 2008; Duarte et al., 2009), including a decrease of primary production while phytoplankton biomass remained stable (Philippart et al., 2007), reappearance of macrophyte communities (de Jonge and de Jong, 2002), and decrease of biomass and frequency of bloom occurrence (Lie et al., 2011). As shallow lakes, coastal lagoons have been particularly subjected to cultural eutrophication process due to nutrient over-enrichment from watersheds and long residence time (Kennish and Paerl, 2010; Glibert et al., 2011). Ecological restoration of coastal lagoons has started recently and studies of this process are still scarce. Given the high variability and dynamics of these systems, we can expect variable and complex restoration trajectories. During the reoligotrophication process in a Mediterranean coastal lagoon (Collos et al., 2009), phytoplankton community changes were similar to those observed in some freshwater lakes, i.e. characterized by the appearance of dinophytes species and small-sized cyanobacteria (Ruggiu et al., 1998, Kamenir and Morabito, 2009). The results suggest some similar responses of lakes and coastal lagoons to re-oligotrophication process. close to Montpellier, a drastic and persistent reduction of anthropogenic nutrient inputs has been achieved since December 2005, leading to a dynamic of ecological restoration. In the 
117 framework of a monitoring network, these lagoons and sixteen other lagoons have been

118 monitored from 2000 to 2013 to assess their eutrophication status. These 24 lagoons

119 presented a large eutrophication gradient ranging from oligotrophy to hypertrophy (Souchu et

120 al., 2010), the most eutrophied lagoons showed phytoplankton dominance with high

121 biomasses $\left(>100 \mu \mathrm{gChla} . \mathrm{L}^{-1}\right)$. The phytoplankton size structure was dominated by small

122 eukaryotic algae $(3-6 \mu \mathrm{m})$ with relatively high growth rates (Bec et al., 2008; 2011).

123 Prior to the reduction in nutrient loadings, the complex of eight lagoons represented a 124 eutrophication gradient ranging from mesotrophic to hypertrophic, including the most 125 hypertrophic lagoons of the region. This context offered us a unique opportunity to study how 126 the initial eutrophication status of lagoons influences the re-oligotrophication trajectories and 127 to assess the success of ecological restoration in these highly degraded systems. We focused 128 on phytoplankton community shifts to investigate the impact of ecological restoration in 129 coastal lagoons for this range of eutrophication levels. Using data from a 13-year monitoring 130 program, we describe changes of phytoplankton biomass and structure (i.e., size class 131 structure and community composition), by comparing two periods: before and after the 132 nutrient reduction. In addition, after implementation of the nutrient reduction, HPLC pigment 133 analyses were added to the monitoring program. This allowed us to study the dynamics of 134 functional and taxonomic groups as well as phytoplankton diversity, based on pigment 135 biomarkers, during re-oligotrophication trajectories.

137 2. Materials and methods

$138 \quad$ 2.1. Studied sites

139 The Palavasian lagoon complex is located on the French Mediterranean coast, near 140 Montpellier city (urban population 250000 inhabitants). Since the 17 th century, infilling and 141 human constructions have compartmentalized a large natural lagoon to give rise to the current 
complex of eight interlinked shallow lagoons covering $38.8 \mathrm{~km}^{2}$ (Fig. 1). A major human intervention was the building of a navigation canal through the natural lagoon oriented NESW, named the Rhône-to-Sète canal which divided the complex into two parts (inland and seafront lagoons). As a result, four of the eight lagoons (i.e., the inland lagoons North Ingril, Vic, Arnel, and Méjean lagoons) are bordered by wetland or salt marshes, which can act as a buffer zone and regulate freshwater inputs from the watershed. Four seafront lagoons (South Ingril, Pierre Blanche, Prévost, and Grec lagoons) are located between the Rhône-to-Sète canal and the lido. Among them, South Ingril and Prévost lagoons are connected to the sea through artificial permanent inlets. The inland lagoons are not directly connected to the sea, but receive seawater indirectly by flow through the adjacent seafront lagoons and the Rhôneto-Sète canal, which has many openings. In addition, canalization of the Lez River oriented perpendicular to the Rhône-to-Sète canal has completed the compartmentalization of lagoon complex. The Lez River, the main freshwater source of the Palavasian lagoons, interacts with some lagoons (Arnel, Méjean, Prévost and Grec) through small channels. These multiple canalizations do not account for sufficient water renewal of lagoon waters. The trophic status and main characteristics of the lagoons as well as the sampling stations are listed in Table 1. For Méjean and Prévost lagoons, two zones corresponding to empirically defined hydrodynamic compartments (Souchu et al., 2010), have been considered for sampling stations (see Table 1).

Effluents from the wastewater treatment plant of the Montpellier city district were discharged into the Lez River until 2005. Through the many channels described above, the nutrients from these effluents have propagated into the different lagoons, which has resulted in on-going eutrophication from 1965 to 2005. The eutrophication gradient ranged from hypertrophy in lagoons close to the Lez river to mesotrophy in the southwestern lagoons (Souchu et al., 2010). In December 2005, the implementation of a new wastewater treatment plant (Maera), 
167 and a diversion of its effluents through an outfall located $11 \mathrm{~km}$ off-shore in the

168 Mediterranean Sea has led to a sudden and drastic reduction of the anthropogenic inputs of 169 nitrogen and phosphorus into the lagoons. This has been estimated as a reduction of $83 \%$ of $170 \quad \mathrm{~N}$ and $70 \%$ of P (Meinesz et al., 2013).

\subsection{Data collection}

173 We exploited the database developed by the Lagoon Monitoring Network (Réseau de Suivi 174 Lagunaire), which comprises data from 2000 to 2013 to assess the eutrophication status of 175 lagoons in the Languedoc-Roussillon region (Souchu et al., 2010). Sampling was carried out 176 during summer periods, when temperature and irradiance are optimal and allow maximal 177 primary production. For the Palavasian lagoon, the ten stations (Table 1) were sampled 178 monthly in June, July, and August from 2000 to 2013. On each date, subsurface water samples were collected with $2 \mathrm{~L}$ polypropylene bottles. Temperature and salinity were recorded with a WTW LF 197 field sensor. This database comprised the concentrations of 181 dissolved inorganic nitrogen $\left(\mathrm{DIN}=\mathrm{NO}_{3}+\mathrm{NH}_{4}+\mathrm{NO}_{2}, \mu \mathrm{M}\right)$ and phosphorus (DIP, $\left.\mu \mathrm{M}\right)$, 182 total nitrogen and phosphorus (TN and TP, $\mu \mathrm{M}$ ). It also included water column chlorophyll a

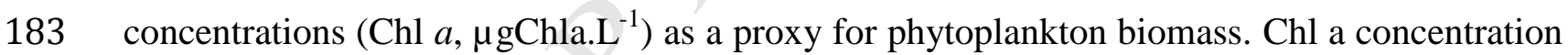
were measured by spectrofluorimetry (Neveux and Lantoine, 1993) with a Perkin-Elmer LS50 B and pico- and nano-phytoplankton abundances $\left(10^{6}\right.$ cells. $\left.\mathrm{L}^{-1}\right)$ counted with a FACSCalibur flow cytometer (Bec et al., 2011). Based on cytometric analysis, different size classes of 187 phytoplankton were identified: Phycoerythrin-rich picocyanobacteria $(\leq 1 \mu \mathrm{m}, \mathrm{PE}-\mathrm{CYAN})$, 188 autotrophic picoeukaryotes $(\leq 3 \mu \mathrm{m}$, PEUK), nanoeukaryotes $(>3 \mu \mathrm{m})$. The analytical 189 protocols have been described in detail by Souchu et al., (2010) and details on filtration, conservation and analysis of phytoplankton samples have been described by Bec et al., 
(2011). Rainfall data were obtained from Météo France (Fréjorgues station, data publicly available online at Comparaison climatologique annuelle - Infoclimat).

\subsection{HPLC determination of pigment diversity}

195 Since 2006, phytoplankton pigment diversity based on HPLC pigment analysis have 196 complemented the database, to investigate on phytoplankton composition by 197 chemotaxonomic identification of main groups. In the laboratory, exact volumes between 250 to $500 \mathrm{ml}$ of water, depending on phytoplankton biomass, were filtered onto Whatman $\mathrm{GF} / \mathrm{F}$ filters (47 $\mathrm{mm}$ diameter) and stored at $-80^{\circ} \mathrm{C}$ until analysis.

Pigments were extracted with $2.5 \mathrm{~mL}$ of $100 \%$ methanol in the dark at $4^{\circ} \mathrm{C}$ for $5 \mathrm{~min}$.

201 Samples were then sonicated 5 times for $10 \mathrm{sec}$ (20 Watts) and spaced by $10 \mathrm{sec}$ in ice to 202 avoid an excessive heating of the extract. After $10 \mathrm{~min}$ in the dark at $4^{\circ} \mathrm{C}$, extracts were 203 filtered on cellulose acetate filters $(0.45 \mu \mathrm{m}$ pore size $)$ to remove filters and cell debris. An 204 aliquot of $600 \mu \mathrm{L}$ was diluted with $150 \mu \mathrm{L}$ of Milli-Q water. A volume of $150 \mu \mathrm{L}$ of this mix 205 was injected to the HPLC system, a Waters D600 equipment. Chlorophylls and carotenoids 206 were detected by a Waters 2996 photo-diode array detector (optic resolution $1.2 \mathrm{~nm}$ ), from 207400 to $700 \mathrm{~nm}$. Chlorophylls and their derivatives were also detected by a 2475 Multi $\lambda$ 208 fluorescence detector, from two canals, to optimize the chlorophyll $a$ (canal A: $412 \mathrm{~nm}$ 209 Excitation - 650 Emission) and the chlorophyll $b$ and $c 2$ detection (canal B: $440 \mathrm{~nm}$ 210 excitation - 650 emission). Pigment extracts were analyzed using the method of Wright et al., 211 (1991) with a flow rate of $1 \mathrm{ml}^{\mathrm{min}}{ }^{-1}$ and a run duration of $29 \mathrm{~min}$. Solvent delivery was 212 programmed following a sequence of three linear gradients as follows (minutes, \% solvent A, $213 \%$ solvent $\mathrm{B}$, \% solvent C): $(0,100,0,0)(2,0,100,0)(18,0,20,80)(21,0,100,0)(24,100,0,0)$

$214(29,100,0,0)$. Solvent A consisted of 80:20 (v/v) methanol: ammonium acetate (0.5 M), 215 solvent B consisted of 90:10 (v/v) acetonitrile : water and solvent C consisted of ethyl acetate. 
216 The HPLC system was calibrated with external standards (DHI Water and Environment,

217 Hørsholm. Denmark). Chromatograms were extracted at $440 \mathrm{~nm}$, and pigments were

218 identified by comparison with a spectral library established from the pigments standards basis

219 and by checking elution order and absorption spectra (Roy et al., 2011), using the software

220 Empower Pro 3. Each peak was checked and the baseline readjusted to minimize errors due to

221 noise. They were then quantified by using peak area, compared to standard calibration curves

222 ( $\left.\mu \mathrm{g} . \mathrm{L}^{-1}\right)$. Pigments dominant in phytoplankton groups were used as markers of these groups.

223 We used fucoxanthin (fuco) as biomarker for fucoxanthin-rich diatoms, peridinin (peri) for

224 dinophytes, and alloxanthin (allo) for cryptophytes (Bustillos-Guzmán et al., 2004). In

225 addition, prasinoxanthin (pras) was used as a biomarker for prasinophytes, while chlorophyll

$226 \quad b(\mathrm{chl} b)$, lutein (lut), violaxanthin (vio), neoxanthin (neo) and zeaxanthin (zea) were

227 considered as characteristic for green algae (Chlorophyta). In the lagoons, the Chlorophyta are

228 mainly represented by chlorophytes and prasinophytes. Zeaxanthin is, however, also present

229 in cyanobacteria (Wright et al., 1991; Sherrard et al., 2006; Eker-Develi et al., 2012). 19'But-

230 fucoxanthin (but-fuco) and 19'Hex-fucoxanthin (hex-fuco) have been used for haptophytes

231 (Wright et al., 1991; Zapata et al., 2000; Paerl et al., 2003).

232

233

\subsection{Statistical analysis}

234 Non-parametric comparisons of $\mathrm{Chl} a$, TP, TN concentrations have been performed by 235 Wilcoxon test (R) to compare before (2000-2005) and after (2006-2013) the diversion of the

236 effluents of the waste water treatment. Spearman's rank correlation has been used to describe

237 the links between environmental parameters and biological variables.

238 The effects of the pre-eutrophication status of the lagoon for its response to the sewage 239 diversion were tested by using two ways ANOVAs (lagoon and time effects for the tested 240 variables: Chl $a$ concentration, pico- and nano-eukaryotes abundances). When data did not 
241 satisfy the conditions of applications (normality, homoscedasticity and independence of

242 residuals), they were log-transformed. If they still did not satisfy conditions, we used

243 Permanova (Anderson, 2001). Pairwise comparison with post-hoc Tukey tests helped to

244 separate lagoons into groups. To assess differences of diversity between lagoon and changes

245 in time, diversity index of Shannon (Ds), and evenness using the number of main

246 phytoplankton groups were estimated, from the annual median of summer pigment

247 concentrations. It represented diversity of main phytoplanktonic groups. Two ways ANOVAs

248 were then performed on these indexes to assess if there were differences between lagoons or

249 between years for these two parameters.

250 To characterize lagoons, spatio-temporal differences in pigment diversity and concentrations

251 were described using non-parametric multivariate analysis of variance (Permanova) and two

252 between-class principal component analyses (between-class PCA), which considers one

253 qualitative variable (here, either the year or the lagoon) (Pélissier et al., 2003). Then, Monte-

254 Carlo tests were used to check significances of differences between groups (Tournois et al.,

255 2013). These PCA were operated on most of the pigments identified, except those rarely

256 identified, with low concentrations, and which did not provide any additional information to

257 this analysis, e.g. phaeophorbid $a$, and 19'but-fucoxanthin. All the statistical analyses were

258 operated with the R software (R Core Team, 2013).

\section{3. Results}

261 3.1 Characterization of the lagoons for the entire monitoring period (2000-2013)

262 During summer, both the average temperature and their variations in the lagoons were very 263 similar, i.e. around $25^{\circ} \mathrm{C}$ with a range between 20 and $31^{\circ} \mathrm{C}$, respectively. A salinity gradient

264 was observed from MW, the less saline lagoon station subject to recurrent freshwater inputs 265 from the Lez River, to IS without freshwater tributaries and connected with the sea by an inlet 
(Table 2). The lagoons also presented a trophic gradient, from mesotrophy (IN, IS) to hypertrophy (MW) based on the Chl $a$ and total nitrogen and phosphorus concentrations (TN, TP). Based on the entire period (2000-2013), median values of chlorophyll ranged from 3.7 $\mu \mathrm{gChl} a . \mathrm{L}^{-1}$ at IS to $83.1 \mu \mathrm{gChl} a . \mathrm{L}^{-1}$ at MW, and median values of TN and TP ranged from 30.7 and $0.9 \mu \mathrm{M}$, respectively at IS to 196 and $12.4 \mu \mathrm{M}$, respectively in MW (Table 2). The trophic and salinity gradients appeared inverse in the lagoons as illustrated by significant negative correlations of the three eutrophication indicators (Chl $a, \mathrm{TN}$ and $\mathrm{TP}$ ) with salinity $\left(\boldsymbol{\rho}_{\text {salinity }}=-0.15 ; \boldsymbol{\rho}_{\mathrm{TN}}=-0.32 ; \boldsymbol{\rho}_{\mathrm{TP}}=-0.31 ; \mathrm{p}\right.$-values $<0.05$, Spearman correlation, $\left.\mathrm{R}\right)$.

Within the phytoplankton community, the highest values of biomasses and abundances were generally observed before the diversion. Thus, the maximum $\mathrm{Chl} a$ concentration was 413 $\mu \mathrm{g} . \mathrm{L}^{-1}$ observed in June 2004 at MW, in the most hypertrophic lagoon, although a strikingly low value of $0.09 \mu \mathrm{g} . \mathrm{L}^{-1}$ was observed in July 2002 at $\mathrm{IN}$, the inland mesotrophic lagoon (IN). Picoeukaryote abundances ranged from $2.9 \times 10^{6}$ cells. $\mathrm{L}^{-1}$ in the inland mesotrophic lagoon (IN) in June 2004 to $2.2 \times 10^{13}$ cells. $\mathrm{L}^{-1}$ in an inland eutrophic lagoon (AN) in July 2004. Nanoeukaryote abundances ranged from no detected cells in several lagoons (GR, IN, IS, MW) in summer 2001 to $2.4 \times 10^{9}$ cells. $L^{-1}$ at ME in June 2003. Phycoerythrin-rich picocyanobacteria were present in low abundances compared to picoeukaryotes. Their abundances ranged from no detected cells in several lagoons (MW, VC and PB), during the summers of 2001 and 2002, to $1.1 \times 10^{8}$ cells.L $\mathrm{L}^{-1}$ at MW in June 2004.

\subsection{Changes in eutrophication indicators before and after effluent diversion}

The TN, TP and chlorophyll $a$ concentrations showed strong variations during the entire period, which were partly related to the changes before and after effluent diversion. These three variables decreased significantly after the nutrient diversion for all the lagoons (Table 3), showing a decrease of the eutrophication permitted by the implementation of the 
291 diversion. Median values of TN, TP and Chl $a$ decreased for the period 2006-2013

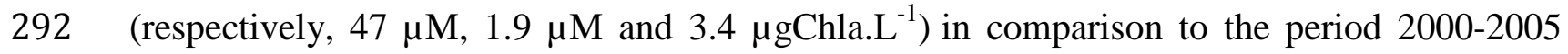

293 (respectively, $84 \mu \mathrm{M}, 3.8 \mu \mathrm{M}$ and $23 \mu \mathrm{gChla} . \mathrm{L}^{-1}$ ). In contrast to the three variables, there was

294 no general trend for the three forms of dissolved inorganic nitrogen $\left(\mathrm{NO}_{3}, \mathrm{NO}_{2}, \mathrm{NH}_{4}\right)$ since

295 the concentrations were not systematically different before and after effluent diversion. $\mathrm{NH}_{4}$

296 represented the main source of DIN before (77\%) and after (71\%) the effluent diversion.

297 Phosphate concentrations $\left(\mathrm{PO}_{4}{ }^{3-}\right)$ showed no significant differences between the two periods.

298 Two-way ANOVA and Permanova (see Methods) showed that the Chl $a$ concentrations, the

299 TN and TP concentrations (for Chl $a$, TN and TP concentrations: Two way ANOVA, p-value

$300<0.05$ ) and the picoeukaryote abundances (Permanova, $p$-values < 0.05) significantly differed

301 among lagoons. Posthoc pairwise Tukey test on Chl $a$ concentrations allowed separating the

302 lagoons into three groups (Table S1).

303 The first group was characterized as hypertrophic and included three lagoons (AR, GR and

304 both stations (ME and MW) of Méjean lagoon). The second group was characterized as

305 eutrophic and comprised three lagoons (PB, VC and both stations (PE and PW) of Prévost

306 lagoon). The third group was characterized as mesotrophic and comprised two lagoons (IN

307 and IS). Within each group, the lagoons showed a similar response to the nutrient reduction

308 (i.e. no significant effect of lagoons within groups according to the Anova and posthoc test, p-

309 value $>0.05)$. Hence, we selected one station in each group to illustrate the impact of trophic

310 status on the lagoon responses to the re-oligotrophication process. For each group, we chose

311 stations in inland lagoons under the direct influence of watershed discharges and more

312 sensitive to potential nutrient loadings than the seafront lagoons. Hence, MW, VC and IN

313 stations were selected to represent the hypertrophic, eutrophic and mesotrophic inland

314 lagoons, respectively. 
315 The impact of the trophic status of the selected lagoons on the phytoplankton responses to the

316 re-oligotrophication process was investigated by comparing Chl $a$ concentrations (Fig. 2) and 317 picoeukaryote and nanoeukaryote abundances (Fig. 3) before and after the diversion. Chl $a$ 318 concentrations were significantly reduced (mean comparison all lagoons, $\mathrm{p}<0.05$ ) with a 319 decrease of $90.4 \%, 65.4 \%$ and $79.9 \%$ in the hypertrophic (MW), eutrophic (VC) and 320 mesotrophic (IN) lagoons, respectively (Fig. 2). Picoeukaryote abundances were reduced by $32160.5 \%$ and by $81.8 \%$ in hypertrophic (MW), and mesotrophic (IN) lagoons, respectively (Fig. 322 3). In contrast, in the eutrophic lagoon (VC) for picoeukaryotes the difference before and after 323 the diversion was not significant (mean comparison, $p$-value $>0.05$, see Fig. $3 B$ ). 324 Abundances of nanoeukaryotes did not show a global trend for the three lagoons (mean 325 comparison all lagoons, p-value > 0.05). Chl $a$ concentrations and picoeukaryote abundances 326 were significantly correlated, showing that the response of the lagoons to the nutrient 327 reduction was particularly well reflected by the picoeukaryotes.

\subsection{Phytoplankton responses after the reduction of effluent nutrient loads}

330 Since 2006, i.e. after nutrient reduction, phytoplankton biomass measured in summer 331 decreased in the three selected lagoons (Fig. 4). The decrease of Chl $a$ concentrations was particularly pronounced between 2006 and 2007 and depended on the trophic status of

333 lagoons. Hence, summer Chl $a$ concentrations were reduced by $87.7 \%$ in MW, $22.4 \%$ in VC 334 and $46.2 \%$ in IN between 2006 and 2007, reaching mean values of $1.7 \mu \mathrm{gChla} \cdot \mathrm{L}^{-1}$ in 335 mesotrophic lagoon (IN) to $9.8 \mu \mathrm{gChla} \cdot \mathrm{L}^{-1}$ in hypertrophic lagoon (MW) in the summer of 3362007 (Fig. 4). Since 2007, the mean Chl $a$ concentrations remained below $10 \mu \mathrm{gChla} . \mathrm{L}^{-1}$ in 337 the three selected lagoons, except in 2011 in the hypertrophic lagoon (MW) where the mean concentration reached $20.1 \mu \mathrm{gChla} . \mathrm{L}^{-1}$. 
340 Since 2006, in parallel to phytoplankton biomass, phytoplankton community pigment

341 composition was determined (Table 3). The total summer concentration of accessory

342 pigments in the three selected lagoons showed the same pattern as observed for Chl $a$

343 concentrations, with the highest pigment concentrations measured in hypertrophic lagoon

344 (MW) and the lowest pigment concentrations measured almost in mesotrophic lagoon (IN).

345 In the hypertrophic lagoon (MW), fucoxanthin was the dominant pigment in 2006, indicating

346 a dominance of the fucoxanthin-rich diatoms (Table 3 and Fig. 5A). Green algae pigments

347 (Chl $b$, lutein, neoxanthin, violaxanthin, prasinoxanthin, and zeaxanthin) showed also high

348 concentrations (more than $5 \mu \mathrm{g} . \mathrm{L}^{-1}$ ) and proportions. We could safely assume that the bulk of

349 zeaxanthin was associated with green algae, since abundances of cyanobacteria were

350 systematically low in the lagoons. In contrast, in the eutrophic lagoon (VC) peridinin showed

351 a high proportion in $2006(45.4 \%)$ indicating a dominance of dinophytes. In the mesotrophic

352 lagoon (IN), proportions of pigments were more equally distributed and fluctuated less than in

353 the other lagoons (Fig. 5) suggesting increased phytoplankton diversity.

354 The temporal patterns of the mean values of the total accessory pigment concentrations were

355 similar to those of phytoplankton chlorophyll $a$ biomass. Concentrations of total accessory

356 pigment strongly decreased between 2006 and 2007, from 80.8\% in hypertrophic (MW),

$35765.8 \%$ in eutrophic (VC) and 50.3\% in mesotrophic (IN) lagoon but increased in 2011, with

$358284 \%, 34.6 \%$ and $15.5 \%$ in the hypertrophic (MW), eutrophic (VC) and mesotrophic (IN)

359 lagoons, respectively.

360 Figure 5 shows the time course of the proportions of the accessory pigments in the three

361 selected lagoons. In the hypertrophic lagoon (MW), the fucoxanthin proportion dropped ($36299.7 \%$ ) between summers 2006 and 2007 and this decrease continued until 2011 (Fig. 5A).

363 This reduction of the fucoxanthin concentration coincided with a strong increase of the 364 proportion of green algae pigments (Chl $b$, lutein, neoxanthin, violaxanthin and zeaxanthin) 
during the same period. The proportion of green algae pigments remained high during all the

366 monitoring and reached almost 80\% during four years (up to 85.4\% in 2007). The year 2011

367 was marked by strong shift in pigment composition with the lowest fucoxanthin concentration

368 (diatoms) and the highest concentrations of green algae pigments. On the contrary, the year 2012 is marked by a decrease of green algae group (4.88\% of the pigment proportions). The alloxanthin, marker of cryptophytes, increased after 2006 and its proportion fluctuated between $0.02 \%$ in 2006 and $22.4 \%$ in 2013. Peridinin, marker of dinophytes, was below $1 \%$ in 2006 and fluctuated between 2007 and 2010. In 2012 when green algae decreased, peridinin concentration strongly increased in association with $\mathrm{Chl} c 2$ and diadinoxanthin and

374 became the main phytoplanktonic group in 2012 and 2013 (peridinin proportion > 30\%).

375 In the eutrophic lagoon (VC), phytoplankton pigment composition was dominated by 376 peridinin, $\mathrm{Chl} c 2$ and dianodinoxanthin during all the monitoring (Fig. 5B). Peridinin 377 proportions were higher in this eutrophic lagoon than in hypertrophic (MW) and mesotrophic 378 (IN) ones. Peridinin tended to decrease until 2011 (-40.5\% in 2008), but highly increased in 3792012 and 2013 (respectively, 51.2 and 38.5\%). In contrast, alloxanthin (cryptophytes) 380 remained stable during the monitoring (up to $10 \%$ in proportions). Diatom pigment increased 381 and fluctuated between 2008 and 2011. As for hypertrophic lagoon, the year 2011 was 382 marked by a temporary increase of green algae pigments (up to $40 \%$ in proportions).

383 In the mesotrophic lagoon (IN), diatoms and cryptophytes pigments (respectively, 384 fucoxanthin and alloxanthin) were dominant during the 8-year monitoring (Fig. 5C). 385 dinophytes and prasinophytes pigments (respectively peridinin and prasinoxanthin) occurred 386 more since 2010. The proportion of green algae pigments fluctuated, during the entire 387 monitoring period, between $2 \%$ in 2008 and $40 \%$ in 2011 . In the three selected lagoons, 388 19'hex-fucoxanthin and 19'but-fucoxantthin were rarely observed (haptophytes). 
Based on the chemotaxonomic analyses, the Shannon diversity and Evenness indices (see

391 Methods) have been calculated as proxies for phytoplankton diversity through the 8-year monitoring period (Figure 6A). Globally, the number of main phytoplankton groups significantly changed during the survey. The richness of main taxonomic groups was significantly lower during the period from 2007 to 2009 (4 or 5 groups) than in 2006 and after 2010 (6 groups). The low diversity during these early years reflected that the community was dominated by diatoms, green algae and cryptophytes. Some differences of the richness also appeared depending on the trophic status of lagoons. It was lower in hypertrophic lagoons than in mesotrophic ones, and lower in mesotrophic lagoons than in eutrophic ones. Pooling all years, there was a significant higher diversity (Shannon diversity index Fig. 6A, $\mathrm{D}_{\mathrm{s}}$ ) in the mesotrophic lagoon (IN) compared to the hypertrophic lagoon (MW), but there was no 401 significant difference between mesotrophic (IN) and the eutrophic (VC) lagoons (two-ways 402 Anova and posthoc test, $\mathrm{p}$-value $>0.05$ ). The evenness showed also significant lower values in the hypertrophic lagoon (MW) compared to the mesotrophic (IN) one, because of the green 404 algae dominance in MW (Figure 6B).

405 In the hypertrophic lagoon (MW), diversity $\mathrm{D}_{\mathrm{s}}$ significantly fluctuated during the 8-year 406 monitoring (Fig. 6A). It firstly decreased from $2006\left(D_{s}=0.49\right)$ to $2007\left(D_{s}=0.20\right)$ and then 407 increased between 2007 and $2009\left(D_{s}=0.70\right)$. It decreased again between 2009 and $2011\left(D_{s}\right.$ 408 close to 0.20$)$ and finally increased to reach a maximal $D_{s}$ value in $2013\left(D_{s}=0.74\right)$. These 409 changes illustrated shifts in phytoplankton community composition. The low values of $\mathrm{D}_{\mathrm{s}}$ in $4102007 / 2008$ and in 2010/2011 are related to the predominance of green algae (Fig. 5A) during 411 these four years. Evenness values showed the same patterns in time as that of the Shannon 412 diversity index (Fig. 6B). It strongly decreased when green algae was the dominant 413 phytoplankton group. After 2011, it increased to reach its highest value in 2013. 
414 In contrast, in the eutrophic lagoon (VC), $\mathrm{D}_{\mathrm{s}}$ increased from 2006 to 2008 (from 0.36 to 0.71 )

415 and stayed relatively stable to reach 0.77 in 2011 . The diversity decreased strongly in 2012

$416\left(D_{s}=0.27\right.$, lowest diversity) and stayed lower in $2013\left(D_{s}=0.50\right)$ than between 2007 and

417 2011. Evenness increased from 2006 to 2009 (0.43 to 0.92) and then fluctuated to finish with

418 an intermediate value $(\mathrm{E}=0.61)$ in 2013 .

419 In the mesotrophic lagoon (IN), diversity and evenness significantly changed over time,

420 decreasing between 2006 and 2008 to reach the lowest values (respectively, 0.47 and 0.63 ,

421 Figure 6) in 2008. From 2009 to 2010, diversity indices increased and stayed relatively stable

422 to reach the highest values in 2013 (respectively, 0.75 and 0.91 , Fig. 6). The lowest diversity 423 and evenness values observed in 2008 were associated to the dominance of two 424 phytoplanktonic groups (diatoms and cryptophytes, Fig. 5C).

425

\subsection{Lagoons trajectories based on pigment diversity}

427 In order to study whether the patterns observed for the selected stations are robust for the 428 entire Palavasian lagoon complex, multifactorial analyses were performed using accessory 429 pigment database from the 10 stations of the complex for the 8-year monitoring. It was 430 observed that pigment composition (concentration and diversity) significantly changed among 431 stations (Permanova, $\mathrm{F}=5.29, \mathrm{df}=9, \mathrm{p}$-value $=0.001)$, and years $($ Permanova, $\mathrm{F}=4.49, \mathrm{df}=$ 4327 , p-value $=0.001$ ). Moreover, the interaction between the two factors also showed a 433 significant effect (Permanova, $\mathrm{F}=1.54, \mathrm{df}=59, \mathrm{p}$-value $=0.001$ ), indicating that the temporal 434 patterns were different among stations. The principal component analysis (PCA) was used on 435 both lagoon stations (Fig. 7) and years (Fig. 8) to elucidate phytoplankton composition 436 patterns in relation to lagoon trophic status and time. For each of the two PCA, the results 437 were significantly different (Monte-Carlo test, $\mathrm{p}$-value $=0.001$ ), although the ellipses 438 representing each group (either lagoons or by years) overlapped. 

stronger signal of haptophytes pigment.

The first PCA showed differences between lagoons (Fig. 7). The first axis explained $71 \%$ of the total variance, and was mainly driven by pigments markers of the green algae (lut, neo, chl $b$, viola and zea), prasinophytes (prasino), diatoms (fuco, chl $c 2$, diadino), associated with total biomass. The second axis explained $16.5 \%$ of the total variance and opposed pigments markers of dinophytes (peri) and cryptophytes (allo) in positive against pigment marker of haptophytes (Hfuc) in negative (Fig. 7A). The first axis is correlated with pigments that are characteristic for the phytoplankton groups which are enhanced by eutrophication (i.e., green algae, diatoms) and a marker of eutrophication ( $\mathrm{Chl} a$ ). The position of the center of gravity of the ten stations in this projection showed two groups of stations: the three most eutrophic stations (ME, MW, GC) strongly separated from the other ones (Fig. 7B-C). The group of hypertrophic stations presented a very large ellipse suggesting a strong variability of pigment concentrations. Their center of gravity was also located close to $\mathrm{Chl} a$, indicating an elevated biomass in these stations compared to the others. More precisely, they are located in two different directions: MW and ME were close to green algae pigments, while GC is closer to pigments from diatoms and cryptophytes indicating a dominance of these three phytoplankton groups with eutrophication. The second group of stations presented lower concentrations of pigments for all the phytoplanktonic groups. Among this group, the centers of gravity of the different stations ranged from positive to negative along the axis 2 , reflecting the trophic gradient ranging from the most (AN) to the less eutrophied (IS) station. Their positions along the second axis reflect some differences in the phytoplankton composition along this gradient. Eutrophic lagoons (AN and $\mathrm{PB}$ ) were close to cryptophytes and dinophytes pigments. On the opposite, mesotrophic lagoons (IN and IS) and Prévost (PE, PW), a lagoon under marine influence, showed a very low phytoplankton biomass and pigment concentrations, and a 
464 The second PCA showed differences between years (Fig. 8). The first axis explained $73 \%$ of

465 the total variance, and was mainly driven by the pigment estimating total phytoplankton

466 biomass ( $\mathrm{Chl} a$ ), pigment markers of diatoms (fuco) or mostly abundant in diatoms (diadino,

$467 \mathrm{Chl} c 2$ ), and pigment marker of prasinophytes (prasino). The second axis explained $17 \%$ of

468 the total variance and was mainly driven by pigment marker of cryptophytes (allo) and green

469 algae in positive, opposed to pigment marker of dinophytes (peri) and haptophytes (19'Hex-

470 fuco) (Fig. 8A). The vectors of the pigment markers of cryptophytes and dinophytes were

471 opposed in the first two planes of the PCA (Fig. 8A). The projection of the pigment

472 composition of the ten stations showed that 2006 differed from other years by a stronger

473 concentration of the pigments driving the first axis (Fig. 8B). The phytoplankton biomass was

474 still high in summer 2006, six months after the diversion (Fig. 4), and diatoms were the main

475 group in the ten stations, with a higher fucoxanthin concentration compared to the other

476 pigments that explain the position of the center gravity of this year on the axis 1 . The

477 following years are distinct from 2006 along the axis 2, showing a change in phytoplankton

478 biomass and composition (Fig. 8B-C). Their position indicate a strong decrease of the Chl $a$

479 concentrations and shifts in phytoplankton composition with a decrease of diatoms and an

480 increase of green algae principally in 2007 and 2008. From 2007 to 2012, each center of

481 gravity showed a displacement along the axis 2, in the direction of the pigment marker of

482 dinophytes, indicating an increase of the occurrence and the concentration of the peridinin in

483 time. 2011 is characterized by a return to pigment markers of green algae, as described in

484 figure 5. Finally, 2013 also differed from the global trend, with a community composition

485 close from those in 2010, less dominated by dinophytes, more balanced between all the 486 pigments identified.

\section{Discussion}


This study represented a unique opportunity to assess the impact of re-oligotrophication

490 processes in shallow Mediterranean coastal lagoons in conjunction with their contrasting trophic states. The results show that phytoplankton responded quickly, and that the amplitude and qualitative changes depend on the prior eutrophication status of the lagoon.

\subsection{Phytoplankton chlorophyll biomass in heavily eutrophied lagoons}

Before the reduction of the nutrient loadings, the 'Palavasian' lagoons were strongly degraded by regular inputs of nitrogen and phosphorus from treated sewage. The most hypertrophic lagoons Méjean and Grec presented Chl $a$ concentrations close to those found in hypertrophic lakes (Jeppesen et al., 1998; Bell and Kalff, 2001). In these lagoons, phytoplankton was the major primary producer, with excessive blooms leading to a complete loss of seagrasses communities and low macroalgal cover probably due to competition for light. Eutrophic symptoms associated to water quality degradation in Palavasian lagoons can be illustrated by the succession of primary producers (Schramm, 1999; Bricker et al., 2008), ranging from a moderate impact, with presence of some macroalgae and seagrasses (IN and IS), to more than the high impact, i.e., dense phytoplankton without macroalgae (ME, MW, GC). The phytoplankton dominance may be related to its strong capacity to compete for dissolved nutrients and light (Cebrian et al., 2014).

After the implementation of the diversion, TN, TP and Chl $a$ biomass responded quickly by a strong decrease within two years after the nutrient reduction, whatever the prior trophic status of the lagoons. Although such a decrease has already been observed during reoligotrophication processes in lacustrine (Ruggiu et al., 1998; Jeppesen et al., 2005; Van Donk et al., 2008), riverine or coastal ecosystems (Kemp et al., 2005; Greening and Janicki, 2006; Xu et al., 2010), it is highlighted that in these coastal lagoons, the response was quick compared to the other systems. Hence, the reduction of chlorophyll $a$ in the Tampa bay took 5 
514 years (Greening and Janicki, 2006), and the reduction of TN and TP in lakes took about 5 and

515 10-15 years, respectively (Jeppesen et al., 2005). The amplitude of the decrease of Chl $a$

516 biomass was strongly linked to the prior trophic status of the lagoon, and was mainly driven

517 by the decrease of picoeukaryote abundances. Steady-state nutrient conditions observed in

518 these lagoons resulted in massive picoeukaryote blooms, observed particularly in eutrophic

519 and hypertrophic lagoons (Table 2). These picoplanktonic blooms often represented the

520 dominant fraction of $\mathrm{Chl} a$ biomass throughout summer (Bec et al., 2011) leading to a strong

521 depletion of nutrients in these highly eutrophied systems (Souchu et al., 2010). These

522 phenomena could explain the absence of significant changes for the inorganic nitrogen and

523 phosphorus concentrations after the reduction of nutrient loadings. The rapidity of the

524 responses of coastal lagoons could also be associated to favorable climatic conditions during

525 the five years (2006-2010), characterized by low or no rainfall during summer (“Comparaison

526 climatologique annuelle - Infoclimat"), reducing non-point source nutrient loads.

\subsection{Phytoplankton functional taxonomic groups}

529 Small cells $(<10 \mu \mathrm{m})$ are the typical dominant phytoplankton in lagoonal algal blooms

530 (Glibert et al., 2010; Bec et al., 2011; Pachés et al., 2014). In the Palavasian complex, 531 phytoplankton community was often dominated by small size classes, most belonging to pico$532(2-3 \mu \mathrm{m})$ and nanoeukaryotes (3-6 $\mu \mathrm{m})$ (Bec et al., 2011). Major functional/taxonomic groups 533 were represented by diatoms, green algae, cryptophytes, and dinophytes. Among them, 534 diatoms, green algae and cryptophytes are functional groups composed of fast-growing algae 535 that may have been favored in response to high and fluctuating nutrient loadings (Paerl et al., 536 2006; Paerl et al., 2010) such as observed in lagoons. However, these functional groups that 537 exhibited contrasting ecological strategies, especially in resource utilization (Litchman et al., 
538 2007), responded differently to the reduction of effluent nutrient loads in conjunction with

539 lagoon environmental changes (i.e. salinity, light, turbulence).

540 Diatoms were present in all the Palavasian lagoons and were particularly dominant in the

541 most eutrophic lagoons in 2006. In many coastal systems, diatoms dominated the

542 phytoplankton community when silicate concentrations were sufficiently high to sustain their

543 growth (Lie et al., 2011; Burford et al., 2012). In Palavasian lagoons, it has been suggested

544 that silicate concentrations may not be limiting for diatom growth (Souchu et al., 2010).

545 Diatoms, with high maximum nutrient uptake rates and high growth rates, may be favored

546 under high or fluctuating nutrients (Litchman et al., 2007) and are not inhibited by turbulence

547 associated with those nutrient regimes (Margalef, 1978). Moreover, diatoms have a high

548 nitrogen affinity, especially small-sized species (Litchman and Klausmeier, 2008; Litchman et

549 al., 2009) making them really competitive compared to others. Thus, this functional group is

550 well adapted to dominate highly eutrophied waters, particularly in coastal waters under

551 freshwater discharges or sewage influence (Paerl et al., 2010; Lie et al., 2011; Gadea et al.,

552 2013). Furthermore, diatoms with low half-saturation constants for irradiance-dependent

553 growth (Litchman et al., 2007) could be more adapted to the low irradiance associated with

554 high chlorophyll concentration in eutrophic and hypertrophic systems (Sommaruga and

555 Robarts, 1997). In terms of seasonal dynamics, diatoms blooms in temperate coastal systems

556 occur mainly in spring but may last during summer if nutrients are continuously supplied and

557 not entirely consumed (Chisholm, 1992; Agawin et al., 2000; Chang et al., 2003). Throughout

558 the year, the continuous discharge of sewage effluent resulted in high nutrient loadings in

559 lagoons that may sustain diatom growth (Lie et al., 2011; Burford et al., 2012). Then, the

560 reduction of effluent nutrient loadings could affect diatom growth, particularly during the dry

561 summer period, leading to the large decrease of fucoxanthin-rich diatoms. This decrease was

562 particularly observed in the hypertrophic lagoons between 2006 and 2007, suggesting a time 
563 lag between reduction of nutrient loading and changes of phytoplankton community

564 composition. In these lagoons, the phytoplankton composition has shifted towards green algae

565 dominance. Temperature also plays an important role in the phytoplankton seasonal

566 succession. Many green algae (Chlorella, Scenedesmus, Cosmarium) have optimal

567 temperature for growth between 25 and $35^{\circ} \mathrm{C}$ (Litchman et al., 2010). After 2006, the shift

568 from diatoms to green algae dominance during summer could thus be explained by the shift in

569 nutrient delivery (decreasing external inputs) and by high summer temperatures.

570 Small Chlorella-like algae were the main component of the picoeukaryote community in the

571 eutrophic Palavasian lagoons before the reduction of nutrient loadings (Bec et al., 2011).

572 After 2006, green algae (chlorophytes and prasinophytes) was also a major functional group

573 of phytoplankton community in the 3-6 $\mu \mathrm{m}$ size range and replaced small diatoms especially

574 into hypertrophic lagoons (ME, MW, GC). Because of their high S:V ratio, efficient growth

575 rates and enhanced nutrient uptake rates (Paerl et al., 2003), green algae appear more

576 competitive than other phytoplankton functional groups to use regenerated forms of nutrients

577 in the lagoons (Glibert et al., 2010). Indeed, benthic fluxes are an important source of 578 nutrients (NID and DIP) in coastal lagoons, especially during summer, and may result in high

$579 \mathrm{NH}_{4}$ efflux from the sediment to the water column (Glibert et al., 2010). Even if the effluent 580 diversion has resulted in a strong reduction of the external nutrient supply, internal supply

581 from benthic stocks related to eutrophication could stimulate phytoplankton growth

582 (McGlathery et al., 2007; Burford et al., 2012). Green algae have abilities to use ammonium

583 from regenerated sedimentary stock (Domingues et al., 2011; Donald et al., 2011) and have

584 particularly high affinity for ammonium uptake compared to diatoms and dinophytes

585 (Litchman et al., 2007).

586 Furthermore, the eutrophication gradient in the Palavasian lagoons is highly linked to 587 freshwaters inputs. Green algae were mainly observed in brackish and hypertrophic lagoons 
such as Méjean lagoon (Table 2). This phytoplankton functional group is tolerant to low

589 salinity as observed in freshwater and brackish coastal lagoons (Coelho et al., 2007;

590 Cartaxana et al., 2009; Pachés et al., 2014) and is often observed in hypertrophic systems such

591 as lagoons under high freshwater inputs (Torres and delRio, 1995; Bonilla et al., 2005) and

592 lakes (Wasmund and Kell, 1991; Hepperle and Krienitz, 2001). So both low salinities and

593 high trophic status could explain the predominance of chlorophytes in some Palavasian

594 lagoons. Flagellates such as Prasinophytes and cryptophytes, present in the most eutrophic

595 lagoons also seems to be promoted by low salinities (Bonilla et al., 2005).

596 Cryptophytes were present in high proportions in the Palavasian lagoons where they can 597 respond quickly to nutrient loads due to their high growth rate (Paerl et al., 2003). In 598 mesotrophic lagoons, it allowed them to be more competitive than picoeukaryotes that were 599 less abundant. This taxonomic group is well adapted to turbid and low light environments 600 such as coastal and estuarine waters due to photoacclimation (phycobilins and alloxanthin 601 pigments) to low light intensities (Bergmann, 2004; Weng et al., 2009; Fischer et al., 2014). 602 Microscopic observations of the ciliate, Mesodinium rubrum, in some Palavasian lagoons 603 suggest that cryptophytes could be also a potential food source for the mixotrophic dinophytes 604 (Paerl et al. 2003; Myung et al., 2011).

605 Dinophytes were scarce or absent in mesotrophic and hypertrophic lagoons in 2006. In many 606 coastal waters, dinophytes occurrence is generally attributed to eutrophication (Anderson et 607 al., 2002; Heisler et al., 2008). However in the coastal lagoons in the South of France, 608 dinophytes have been reported mainly for oligotrophic and mesotrophic marine lagoons 609 (Collos et al., 2009; Bec et al., 2011). Hence, it was suggested that habitat disturbance, 610 species displacement and low turbulence could favor dinophytes occurrences. Due to 611 relatively low growth rates, it is expected that this functional group is better adapted under 612 low-nutrient and low turbulence conditions (Margalef, 1978). After the nutrient reduction, all 
613 lagoons showed increasing proportion and occurrence of peridinin-rich dinophytes with time.

614 In eutrophic lagoons, the phytoplankton composition has shifted from diatoms to dinophytes.

615 This shift has already been observed during the re-oligotrophication of coastal ecosystems 616 caused by a reduction of phosphorus loadings (Yamamoto, 2003; Collos et al., 2009). In these 617 systems, the depletion of inorganic phosphorus may have led to blooms of dinophytes that can 618 utilize dissolved organic phosphorus (Seto Inland Sea) or picocyanobacteria as an additional 619 resource (Thau lagoon). Thus, the ability of dinophytes to grow while the availability of 620 inorganic nutrients decreases could be related to their ability to supplement their photo621 autotrophy by mixotrophy (Smayda and Reynolds, 2003; Litchman et al., 2007). Mixotrophy 622 could provide a unique resource niche under steady-state summertime conditions in coastal 623 and estuarine environments (Stickney et al., 2000). In freshwater lakes, mixotrophic flagellate 624 species (dinophytes, chrysophytes, cryptophytes) have appeared or increased during the re625 oligotrophication process (Gaedke, 1998; Anneville and Pelletier, 2000; Van Donk et al., 626 2008). In lake Constance, it has been argued that the mixotrophic properties of Dinobryon 627 (chrysophyte) are an advantage in phosphorus-poor waters and its increasing biomass may be 628 explained by the increasing underwater light due to the decreasing biomass of the other 629 phytoplankton groups (Kamjunke et al., 2007). The authors suggested that the increased 630 underwater light availability promoted the autotrophic energy gain (phagotrophic phosphorus 631 gain) of Dinobryon. On the other hand, as large phytoplankton biomass blooms decreased, the 632 shift in species composition may have led to greater prevalence of some species such as 633 dinophytes that can fill that niche (Anderson et al., 2002).

\subsection{Phytoplankton trajectories during re-oligotrophication process}

636 The functional approach was used to understand the phytoplankton community patterns since 637 the re-oligotrophication started in the Palavasian lagoons. The analysis of four major 
638 functional phytoplankton groups, through algal strategies and adaptations, revealed that the trajectories of the phytoplankton community displayed a complex response to changing nutrient loads over time. The trajectories of coastal ecosystems during re-oligotrophication

641 may be more complex than expected as other control factors maybe changing at the same time

642 (Duarte et al., 2009).

643 During the 8-year lagoon monitoring, the decrease of chlorophyll biomass is associated to 644 changes of phytoplankton diversity that are strongly linked to the prior trophic status of the lagoons. Diversity, evenness and richness of phytoplanktonic groups were higher in mesotrophic lagoons than in the most eutrophic ones. In ecosystems with high production,

647 diversity is generally reduced by competitive exclusion while it is maximized at 648 "intermediate" disturbance and production level (Huston, 1979; Duarte et al., 2006 and 649 references therein). The diversity changes reflected the modifications of the community 650 structure in response of the reduction of effluent nutrient loads. While Chl $a$, TN and TP concentrations decreased strongly and quickly, the diversity of main phytoplanktonic groups 652 responded to the nutrient reduction over a much longer period. Throughout the monitoring, 653 the diversity patterns were marked by a strong variability in eutrophic and hypertrophic 654 lagoons whereas phytoplankton community structure reached the highest diversity and 655 stability (since 2010) in mesotrophic lagoons. Eutrophic and hypertrophic lagoons are still 656 subjected to environmental fluctuations (i.e. fluctuating nutrient supply) or disturbance related 657 to freshwater inputs from multiple canalization (See Methods) that can explain the 658 fluctuations of phytoplankton diversity. Moreover, as high nutrient availability tends to 659 reduce phytoplankton diversity by favoring fast-growing species (Huston, 1979; Duarte et al., 660 2006), algal coexistence should be facilitated and thus phytoplankton diversity should 661 increase in time with the decreasing of nutrient availability in lagoons as observed in 662 mesotrophic ones. 
Therefore, the responses of lagoon phytoplankton community to re-oligotrophication are not a

664 linear process that remains vulnerable to potential nutrient loads associated to rain events or to

665 interannual climate variations. Indeed, as during the summer of 2011, the re-oligotrophication

666 trend could be temporarily reversed by climatic conditions. The chlorophyll biomass and the

667 proportion of chlorophytes increased in all lagoons. This year presented a record of elevated

668 air temperature $\left(1.5^{\circ} \mathrm{C}\right.$ warmer than the $1900-2011$ average $)$. The spring was exceptionally

669 warm and allowed early phytoplankton growth while summer presented particularly

670 important rainfall and storm events, bringing nutrients to the lagoons (www.meteofrance.fr).

671 The year 2011 represented an exception compared to the 8-year lagoon monitoring period but

672 showed that the phytoplankton trajectories are fragile and can be reversed. In coastal

673 ecosystems, the re-oligotrophication may follow the reduction of sewage nutrient inputs but

674 may be affected by anthropogenic disturbance or by natural phenomena including rainfall 675 events or record flood years (Saeck et al., 2013).

676 This study showed that changes of phytoplankton community structure and composition are a

677 first step in restoration of water column for the Palavasian lagoons. Even if external nutrient

678 loadings decreased, high internal nutrient loads that have accumulated in the sediments during

679 the eutrophication period may release nutrients in the water column, particularly during 680 summer, delaying the recovery of lagoons in the long term as observed for lakes (Jeppesen et 681 al., 2005; Sondergaard et al., 2007). The increase of the light penetration, permitted by the 682 reduction of the phytoplankton biomass, initiated recently a shift among the primary 683 producers, with the reappearance of the macroalgae particularly in the most eutrophied 684 lagoons (work in progress). Benthic macroalgae can outcompete phytoplankton for nutrients, especially if the major nutrient supply is internal loading form mineralization from sediments

686 (McGlathery et al., 2007). This primary producer reduces the flux of nutrients from the 687 sediment to the water column, which limits the supply of nutrients for phytoplankton growth. 
688 By competition for nutrient and light, macroalgae could directly influence the phytoplankton

689 diversity and community structure during the re-oligotrophication process. Inversely to the

690 shift from benthic to pelagic-dominated primary producers occurring during eutrophication

691 (Bricker et al., 2008), Palavasian lagoons could expect a shift from a system pelagic-

692 dominated productivity based on phytoplankton to a more benthic-dominated system based on

693 macroalgae and seagrasses.

694

695 Acknowledgements

696 Amandine Leruste was supported by a $\mathrm{PhD}$ fellowship from the French Ministry of 697 Education, Higher Education and Scientific Research attributed by the Doctoral School 698 SIBAGHE in Montpellier. This paper uses data from the Lagoon Monitoring Network 699 (Réseau de Suivi Lagunaire) funded by Agence de l'Eau, Région Languedoc-Roussillon and 700 Ifremer. We thank the staff of the Ifremer laboratories in Languedoc-Roussillon for data

701 collection. We thank Annie Pastoureaud and André Vaquer for having initiated the HPLC 702 pigment analysis in the framework of the Lagoon Monitoring Network. This paper is 703 dedicated to the memory of Yves Collos (1949-2015). 
Agawin, N.S.R., Duarte, C.M., Agusti, S., 2000. Nutrient and temperature control of the Contribution of Picoplankton to Phytoplankton Biomass and Production. Limnol. Oceanogr. $45,591-600$.

Anderson, D.M., Glibert, P.M., Burkholder, J.M., 2002. Harmful algal blooms and doi:10.1007/BF02804901

Anderson, M.J., 2001. A new method for non-parametric multivariate analysis of variance. Austral Ecol. 26, 32-46. doi:10.1111/j.1442-9993.2001.01070.pp.x

Anneville, O., Pelletier, J.P., 2000. Recovery of lake Geneva from eutrophication: quantitative response of phytoplankton. Arch. Hydrobiol. 148, 607-624.

Bec, B., Collos, Y., Vaquer, A., Mouillot, D., Souchu, P., 2008. Growth rate peaks at intermediate cell size in marine photosynthetic picoeukaryotes. Limnol. Oceanogr. 53, 863867. doi:10.4319/lo.2008.53.2.0863

Bec, B., Collos, Y., Souchu, P., Vaquer, A., Lautier, J., Fiandrino, A., Benau, L., Orsoni, V., Laugier, T., 2011. Distribution of picophytoplankton and nanophytoplankton along an anthropogenic eutrophication gradient in French Mediterranean coastal lagoons. Aquat. Microb. Ecol. 63, 29-45. doi:10.3354/ame01480

Bell, T., Kalff, J., 2001. The contribution of picophytoplankton in marine and freshwater systems of different trophic status and depth. Limnol. Oceanogr. 46, 1243-1248.

Bergmann, T., 2004. The physiological ecology and natural distribution patterns of Cryptomonas Aagae in coastal aquatic ecosystems. New Brunswick Rutgers, The State University of New Jersey.

Boesch, D.F., 2002. Challenges and opportunities for science in reducing nutrient overenrichment of coastal ecosystems. Estuaries 25, 886-900. doi:10.1007/BF02804914 Bonilla, S., Conde, D., Aubriot, L., Perez, M.D., 2005. Influence of hydrology on phytoplankton species composition and life strategies in a subtropical coastal lagoon periodically connected with the Atlantic Ocean. Estuaries 28, 884-895. doi:10.1007/BF02696017

Bricker, S.B., Longstaf, B., Dennison, W., Jones, A., Boicourt, K., Wicks, C., Woerner, J., 2008. Effects of nutrient enrichment in the nation's estuaries: A decade of change. Harmful Algae 8, 21-32. doi:10.1016/j.hal.2008.08.028

Bullock, J.M., Aronson, J., Newton, A.C., Pywell, R.F., Rey-Benayas, J.M., 2011.

Restoration of ecosystem services and biodiversity: conflicts and opportunities. Trends Ecol. Evol. 26, 541-549. doi:10.1016/j.tree.2011.06.011

Burford, M.A., Revill, A.T., Clementson, J.S.L., 2012. Effect of sewage nutrients on algal production, biomass and pigments in tropical tidal creeks. Mar. Pollut. Bull. 64, 2671-2680. Bustillos-Guzmán, J., Gárate-Lizárraga, I., López-Cortés, D., Hernández-Sandoval, F., 2004. The use of pigment "fingerprints" in the study of harmful algal blooms. Rev. Biol. Trop. 52 Suppl 1, 17-26.

Carlier, A., Riera, P., Amouroux, J.-M., Bodiou, J.-Y., Desmalades, M., Gremare, A., 2008. Food web structure of two Mediterranean lagoons under varying degree of eutrophication. J. Sea Res. 60, 287-298. doi:10.1016/j.seares.2008.10.006

Cartaxana, P., Mendes, C.R., Brotas, V., 2009. Phytoplankton and ecological assessment of brackish and freshwater coastal lagoons in the Algarve, Portugal. Lakes Reserv. Res. Manag. 14, 221-230. doi:10.1111/j.1440-1770.2009.00405.x

Cebrian, J., Corcoran, D., Lartigue, J., 2014. Eutrophication-driven shifts in primary producers in shallow coastal systems: implications for system functional Change. Estuaries Coasts 37, S180-S197. doi:10.1007/s12237-013-9689-x 
Chang, F.H., Zeldis, J., Gall, M., Hall, J., 2003. Seasonal and spatial variation of phytoplankton assemblages, biomass and cell size from spring to summer across the northeastern New Zealand continental shelf. J. Plankton Res. 25, 737-758. doi:10.1093/plankt/25.7.737 Chisholm, S.W., 1992. Phytoplankton size, in: Falkowski, P.G., Woodhead, A.D., Vivirito, K. (Eds.), Primary productivity and biogeochemical bycles in the sea, Environmental Science Research. Springer US, pp. 213-237. Cloern, J.E., 2001. Our evolving conceptual model of the coastal eutrophication problem. Mar. Ecol.-Prog. Ser. 210, 223-253. doi:10.3354/meps210223 Coelho, S., Gamito, S., Perez-Ruzafa, A., 2007. Trophic state of Foz de Almargem coastal lagoon (Algarve, South Portugal) based on the water quality and the phytoplankton community. Estuar. Coast. Shelf Sci. 71, 218-231. doi:10.1016/j.ecss.2006.07.017 Collos, Y., Bec, B., Jauzein, C., Abadie, E., Laugier, T., Lautier, J., Pastoureaud, A., Souchu, P., Vaquer, A., 2009. Oligotrophication and emergence of picocyanobacteria and a toxic dinoflagellate in Thau lagoon, southern France. J. Sea Res 61, 68-75. doi:10.1016/j.seares.2008.05.008 Comparaison climatologique annuelle Infoclimat[http://www.infoclimat.fr/climatologie/annee/2016/montpellierfrejorgues/valeurs/07643.html], 20 of August 2015.

De Jonge, V.N., de Jong, D.J., 2002. Ecological restoration in coastal areas in the Netherlands: concepts, dilemmas and some examples. Hydrobiologia 478, 7-28. doi:10.1023/A:1021014310819

De Jonge, V.N., Elliott, M. 2001. Eutrophication. In: J Steele, S Thorpe \& K Turekian (Eds.) Encyclopedia of Ocean Sciences. Volume 2, Academic Press, London.p852-870. Domingues, R.B., Barbosa, A.B., Sommer, U., Galvao, H.M., 2011. Ammonium, nitrate and phytoplankton interactions in a freshwater tidal estuarine zone: potential effects of cultural eutrophication. Aquat. Sci. 73, 331-343. doi:10.1007/s00027-011-0180-0 Donald, D.B., Bogard, M.J., Finlay, K., Leavitt, P.R., 2011. Comparative effects of urea, ammonium, and nitrate on phytoplankton abundance, community composition, and toxicity in hypereutrophic freshwaters. Limnol. Oceanogr. 56, 2161-2175. doi:10.4319/lo.2011.56.6.2161

Duarte, C.M., Conley, D.J., Carstensen, J., Sanchez-Camacho, M., 2009. Return to Neverland: shifting baselines affect eutrophication restoration targets. Estuaries Coasts 32, 29-36. doi:10.1007/s12237-008-9111-2 Duarte, P., Macedo, M.F., da Fonseca, L.C., 2006. The relationship between phytoplankton diversity and community function in a coastal lagoon. Hydrobiologia 555, 3-18. doi:10.1007/s10750-005-1101-9

Eker-Develi, E., Berthon, J.-F., Canuti, E., Slabakova, N., Moncheva, S., Shtereva, G., Dzhurova, B., 2012. Phytoplankton taxonomy based on CHEMTAX and microscopy in the northwestern Black Sea. J. Mar. Syst. 94, 18-32. doi:10.1016/j.jmarsys.2011.10.005 Elliott, M., Burdon, D., Hemingway, K.L., Apitz, S.E., 2007. Estuarine, coastal and marine ecosystem restoration: confusing management and science - a revision of concepts. Estuar. Coast. Shelf Sci. 74, 349-366. doi:10.1016/j.ecss.2007.05.034 Fischer A.M., Ryan, J.P., Levesque , C., Welschmeyer, N. 2014. Characterizing estuarine plume discharge into the coastal ocean using fatty acid biomarkers and pigment analysis. Marine Environmental Research 99, 106-116. Gadea, I., Rodilla, M., Sospedra, J., Falco, S., Morata, T., 2013. Seasonal Dynamics of the Phytoplankton Community in the Gandia Coastal Area, Southern Gulf of Valencia. Thalassas 29, 35-58.

Gaedke, U., 1998. Functional and taxonomical properties of the phytoplankton community of 
large and deep Lake Constance: interannual variability and response to re-oligotrophication (1979-1993). Arch. Hydrobiol. Spec. Issues Adv. Limnol. 53, 119-141. Glibert, P.M., Boyer, J.N., Heil, C.A., Madden, C., Sturgis, B., Wazniak, C.S. 2010. Blooms in lagoons: different from those of river-dominated estuaries. In: Kennish M, Paerl H (eds) Coastal lagoons: critical habitats of environmental change. CRC Press, Boca Raton, FL. Glibert, P.M., Fullerton, D., Burkholder, J.M., Cornwell, J.C., Kana, T.M., 2011. Ecological stoichiometry, biogeochemical cycling, invasive species, and aquatic food webs: San Francisco estuary and comparative Systems. Rev. Fish. Sci. 19, 358-417. doi: 10.1080/10641262.2011.611916

Greening, H., Janicki, A., 2006. Toward reversal of eutrophic conditions in a subtropical estuary: water quality and seagrass response to nitrogen loading reductions in Tampa Bay, Florida, USA. Environ. Manage. 38, 163-178. doi:10.1007/s00267-005-0079-4 Heemsbergen, D.A., Berg, M.P., Loreau, M., van Hal, J.R., Faber, J.H., Verhoef, H.A., 2004. Biodiversity effects on soil processes explained by interspecific functional dissimilarity. Science 306, 1019-1020. doi:10.1126/science.1101865 Heisler, J., Glibert, P.M., Burkholder, J.M., Anderson, D.M., Cochlan, W., Dennison, W.C., Dortch, Q., Gobler, C.J., Heil, C.A., Humphries, E., Lewitus, A., Magnien, R., Marshall, H.G., Sellner, K., Stockwell, D.A., Stoecker, D.K., Suddleson, M., 2008. Eutrophication and harmful algal blooms: A scientific consensus. Harmful Algae 8, 3-13. doi:10.1016/j.hal.2008.08.006

Hepperle D, Krienitz L (2001) Systematics and ecology of chlorophyte picoplankton in German inland waters along a nutrient gradient. Int Rev Hydrobiol 86, 269-284. Ho, A.Y.T., Xu, J., Yin, K., Yuan, X., He, L., Jiang, Y., Lee, J.H.W., Anderson, D.M., Harrison, P.J., 2008. Seasonal and spatial dynamics of nutrients and phytoplankton biomass in Victoria Harbour and its vicinity before and after sewage abatement. Mar. Pollut. Bull. 57, 313-324. doi:10.1016/j.marpolbul.2008.04.035

Huston, M., 1979. A General Hypothesis of Species Diversity. Am. Nat. 113, 81-101. Ibelings, B.W., Portielje, R., Lammens, E.H.R.R., Noordhuis, R., van den Berg, M.S., Joosse, W., Meijer, M.L., 2007. Resilience of alternative stable states during the recovery of shallow lakes from eutrophication: Lake Veluwe as a case study. Ecosystems 10, 4-16. doi:10.1007/s10021-006-9009-4

Jeppesen, E., Sondergaard, M., Jensen, J.P., Mortensen, E., Hansen, A.M., Jorgensen, T., 1998. Cascading trophic interactions from fish to bacteria and nutrients after reduced sewage loading: An 18-year study of a shallow hypertrophic lake. Ecosystems 1, 250-267. doi:10.1007/s100219900020 Jeppesen, E., Sondergaard, M., Jensen, J.P., Havens, K.E., Anneville, O., Carvalho, L., Coveney, M.F., Deneke, R., Dokulil, M.T., Foy, B., Gerdeaux, D., Hampton, S.E., Hilt, S., Kangur, K., Kohler, J., Lammens, E., Lauridsen, T.L., Manca, M., Miracle, M.R., Moss, B., Noges, P., Persson, G., Phillips, G., Portielje, R., Schelske, C.L., Straile, D., Tatrai, I., Willen, E., Winder, M., 2005. Lake responses to reduced nutrient loading - an analysis of contemporary long-term data from 35 case studies. Freshw. Biol. 50, 1747-1771. doi:10.1111/j.1365-2427.2005.01415.x Jeppesen, E., Sondergaard, M., Meerhoff, M., Lauridsen, T.L., Jensen, J.P., 2007. Shallow lake restoration by nutrient loading reduction - some recent findings and challenges ahead. Hydrobiologia 584, 239-252. doi:10.1007/s10750-007-0596-7

Kamenir, Y., Morabito, G., 2009. Lago Maggiore oligotrophication as seen from the longterm evolution of its phytoplankton taxonomic size structure. J. Limnol. 68, 146-161. Kamjunke, N., Henrichs, T., Gaedke, U., 2007. Phosphorus gain by bacterivory promotes the mixotrophic flagellate Dinobryon spp.during re-oligotrophication. J. Plankton Res. 29, 39-46 doi:10.1093/plankt/fbl054 
Katsiapi, M., Moustaka-Gouni, M., Vardaka, E., Kormas, K.A., 2013. Different phytoplankton descriptors show asynchronous changes in a shallow urban lake (L. Kastoria, Greece) after sewage diversion. Fundam. Appl. Limnol. 182, 219-230. doi:10.1127/18639135/2013/0362

Kemp, W.M., Boynton, W.R., Adolf, J.E., Boesch, D.F., Boicourt, W.C., Brush, G., Cornwell, J.C., Fisher, T.R., Glibert, P.M., Hagy, J.D., Harding, L.W., Houde, E.D., Kimmel, D.G., Miller, W.D., Newell, R.I.E., Roman, M.R., Smith, E.M., Stevenson, J.C., 2005.

Eutrophication of Chesapeake Bay: historical trends and ecological interactions. Mar. Ecol. Prog. Ser. 303, 1-29.

Kennish M. and H. W. Paerl. 2010. Coastal Lagoons: Critical Habitats of Environmental Change. CRC Marine Science Series, CRC Press, Boca Raton, FL.

Knopper, B., 1994. Aquatic primary production in coastal lagoons, in: Coastal Lagoon Processes. Amsterdam, p. p 243-287.

Lie, A.A.Y., Wong, C.K., Lam, J.Y.C., Liu, J.H., Yung, Y.K., 2011. Changes in the nutrient ratios and phytoplankton community after declines in nutrient concentrations in a semienclosed bay in Hong Kong. Mar. Environ. Res. 71, 178-188.

doi:10.1016/j.marenvres.2011.01.001

Litchman, E., Klausmeier, C.A., Schofield, O.M., Falkowsk, P.G., 2007. The role of functional traits and trade-offs in structuring phytoplankton communities: scaling from cellular to ecosystem level. Ecology Letters 10, 1170-1181. doi: 10.1111/j.14610248.2007.01117.x

Litchman, E., Klausmeier, C.A., 2008. Trait-based community ecology of phytoplankton, in: Annual Review of Ecology Evolution and Systematics. Annual Reviews, Palo Alto, pp. 615639.

Litchman, E., Klausmeier, C.A., Yoshiyama, K., 2009. Contrasting size evolution in marine and freshwater diatoms. Proc. Natl. Acad. Sci. U. S. A. 106, 2665-2670. doi:10.1073/pnas.0810891106

Litchman, E., Pinto, P. de T., Klausmeier, C.A., Thomas, M.K., Yoshiyama, K., 2010. Linking traits to species diversity and community structure in phytoplankton. Hydrobiologia 653, 15-28. doi:10.1007/s10750-010-0341-5 Livingston, R.J., 2000. Eutrophication processes in coastal systems. CRC Press.

McGlathery, K.J., Sundback, K., Anderson, I.C., 2007. Eutrophication in shallow coastal bays and lagoons: the role of plants in the coastal filter. Mar. Ecol. Prog. Ser. 348, 1-18. doi: 10.3354/meps07132

Margalef, R., 1978. Life-forms of phytoplankton as survival alternatives in an unstable environment. Ocean. Acta 1, 493-509.

Meinesz, C, Derolez, V., Bouchoucha, M., 2013. Base de données "pressions sur les lagunes méditérranéennes" - Analyse des liens état - pression. Report in French. Agence de l'Eau Rhône-Méditeranée-Corse, Montpellier, France

Myung, G., Kim, H.S., Park, J.S., Park, M.G., Yih, W., 2011. Population growth and plastid type of Myrionecta rubra depend on the kinds of available cryptomonad prey. Harmful Algae 10, 536-541. doi:10.1016/j.hal.2011.04.005

Neveux, J., Lantoine, F., 1993. Spectrofluorometric assay of chlorophylls and phaeopigments using the least squares approximation technique. Deep Sea Res. Part Oceanogr. Res. Pap. 40, 1747-1765. doi:10.1016/0967-0637(93)90030-7

Nixon, S.W., 1995. Coastal marine eutrophication - a definition, social causes, and future concerns. Ophelia 41, 199-219.

Nixon, S.W., 2009. Eutrophication and the macroscope. Hydrobiologia 629, 5-19. doi:10.1007/s10750-009-9759-z

Pachés, M., Romero, I, Martinez-Guijarro, R., Marti, C.M., Ferrer, J., 2014. Changes in 
904

905

906

907

908

909

910

911

912

913

914

915

916

917

918

919

920

921

922

923

924

925

926

927

928

929

930

931

932

933

934

935

936

937

938

939

940

941

942

943

944

945

946

947

948

949

950

951

952

953

phytoplankton composition in a Mediterranean coastal lagoon in the Cullera Estany (Comunitat Valenciana, Spain) Water and Environment Journal 28, 135-144. doi:10.1111/wej.12020

Paerl, H.W., Valdes, L.M., Pinckney, J.L., Piehler, M.F., Dyble, J., Moisander, P.H., 2003. Phytoplankton photopigments as indicators of estuarine and coastal eutrophication. BioScience 53, 953-964.

Paerl, H.W., Valdes, L.M., Peierls, B.L., Adolf, J.E., Harding, Jr., L.W., 2006. Anthropogenic and climatic influences on the eutrophication of large estuarine ecosystems. Limnol. Oceanogr. 51, 448-462.

Paerl, H.W., Rossignol, K.L., Hall, S. N., Peierls, B.L., Wetz, M.S. 2010. Phytoplankton community indicators of short- and long-term ecological change in the anthropogenically and climatically impacted Neuse River estuary, North Carolina, USA. Estuaries and Coasts 33, 485-497.

Philippart, C.J.M., Beukema, J.J., Cadée, G.C., Dekker, R., Goedhart, P.W., van Iperen, J.M., Leopold, M.F., Herman, P.M.J., 2007. Impacts of nutrient reduction on coastal communities. Ecosystems 10, 96-119. doi:10.1007/s10021-006-9006-7

R Core Team. (2013). R: A language and environment for statistical computing. R Foundation for Statistical Computing,Vienna, Austria. URL http://www.R-project.org/. Roy, S., Llewellyn, C.A., Egeland, E.S., 2011. Phytoplankton Pigments: Characterization, Chemotaxonomy and Applications in Oceanography. Cambridge University Press.

Ruggiu, D., Morabito, G., Panzani, P., Pugnetti, A., 1998. Trends and relations among basic phytoplankton characteristics in the course of the long-term oligotrophication of Lake Maggiore (Italy). Hydrobiologia 370, 243-257.

Scheffer, M., Hosper, S.H., Meijer, M.-L., Moss, B., Jeppesen, E., 1993. Alternative equilibria in shallow lakes. Trends Ecol. Evol. 8, 275-279. doi:10.1016/0169-5347(93)90254$\mathrm{M}$

Scheffer, M., Carpenter, S.R., 2003. Catastrophic regime shifts in ecosystems: linking theory to observation. Trends Ecol. Evol. 18, 648-656. doi:10.1016/j.tree.2003.09.002 Schramm, W., 1999. Factors influencing seaweed responses to eutrophication: some results from EU-project EUMAC. J. Appl. Phycol. 11, 69-78. doi:10.1023/A:1008076026792 Sherrard, N.J., Nimmo, M., Llewellyn, C.A., 2006. Combining HPLC pigment markers and ecological similarity indices to assess phytoplankton community structure: an environmental tool for eutrophication? Sci. Total Environ. 361, 97-110. doi:10.1016/j.scitotenv.2005.08.058 Smayda, T.J., Reynolds, C.S., 2003. Strategies of marine dinoflagellate survival and some rules of assembly. J. Sea Res. 49, 95-106. doi:10.1016/S1385-1101(02)00219-8 Smith, V.H., 2006. Responses of estuarine and coastal marine phytoplankton to nitrogen and phosphorus enrichment. Limnol. Oceanogr. 51, 377-384.

doi:10.4319/lo.2006.51.1_part_2.0377

Sommaruga, R., Robarts, R.D., 1997. The significance of autotrophic and heterotrophic picoplankton in hypertrophic ecosystems. FEMS Microbiol Ecol 24,187-200.

Sondergaard, M., Jensen, J.P., Jeppesen, E., 2003. Role of sediment and internal loading of phosphorus in shallow lakes. Hydrobiologia 506, 135-145.

doi:10.1023/B:HYDR.0000008611.12704.dd

Sondergaard, M., Jeppesen, E., Lauridsen, T.L., Skov, C., Van Nes, E.H., Roijackers, R., Lammens, E., Protielje, R., 2007. Lake restoration: successes, failures and long-term effects. J. Apll. Ecol. 44, 1095-1105. doi: 10.1111/j.1365-2664.2007.01363.x

Souchu, P., Bec, B., Smith, V.H., Laugier, T., Fiandrino, A., Benau, L., Orsoni, V., Collos, Y., Vaquer, A., 2010. Patterns in nutrient limitation and chlorophyll a along an anthropogenic eutrophication gradient in French Mediterranean coastal lagoons. Can. J. Fish. Aquat. Sci. 67, 743-753. doi:10.1139/F10-018 
954

955

956

957

958

959

960

961

962

963

964

965

966

967

968

969

970

971

972

973

974

975

976

977

978

979

980

981

982

983

984

985

986

987

988

989

990

991

Stickney, H.L., Hood, R.R., Stoecker, D.K., 2000. The impact of mixotrophy on planktonic marine ecosystems. Ecol. Model. 125, 203-230. doi:10.1016/S0304-3800(99)00181-7

Torres, E.S., delRio, J.G., 1995. Spatial variations of phytoplankton community structure in a highly eutrophicated coast of the Western Mediterranean Sea. Water Sci. Technol. 32, 313322. doi:10.1016/0273-1223(96)00104-7

Tournois, J., Ferraton, F., Velez, L., McKenzie, D.J., Aliaume, C., Mercier, L., Darnaude, A.M., 2013. Temporal stability of otolith elemental fingerprints discriminates among lagoon nursery habitats. Estuar. Coast. Shelf Sci. 131, 182-193. doi:10.1016/j.ecss.2013.07.006 Van Donk, E., Hessen, D.O., Verschoor, A.M., Gulati, R.D., 2008. Re-oligotrophication by phosphorus reduction and effects on seston quality in lakes. Limnologica 38, 189-202. doi:10.1016/j.limno.2008.05.005

Vidal, M., Duarte, C.M., Sanchez, M.C., 1999. Coastal eutrophication research in Europe: Progress and imbalances. Mar. Pollut. Bull. 38, 851-854. doi:10.1016/S0025326X(99)00030-2

Violle, C., Navas, M.-L., Vile, D., Kazakou, E., Fortunel, C., Hummel, I., Garnier, E., 2007. Let the concept of trait be functional! Oikos 116, 882-892. doi:10.1111/j.00301299.2007.15559.x

Wasmund, N., Kell, V., 1991. Characterization of brackish coastal waters of different trophic levels by means of phytoplankton biomass and primary production. Int. Rev. Gesamten Hydrobiol. Hydrogr. 76, 361-370. doi:10.1002/iroh.19910760309

Weng, H.-X., Qin, Y.-C., Sun, X.-W., Chen, X.-H., Chen, J.-F., 2009. Effects of light intensity on the growth of Cryptomonas sp (Cryptophyceae). Environ. Geol. 57, 9-15. doi:10.1007/s00254-008-1277-1

Worm, B., Lotze, H.K., 2006. Effects of eutrophication, grazing, and algal blooms on rocky shores. Limnol. Oceanogr. 51, 569-579.

Wright, S., Jeffrey, S., Mantoura, R., Llewellyn, C., Bjornland, T., Repeta, D., Welschmeyer, N., 1991. Improved HPLC method for the analysis of chlorophylls and carotenoids in marine phytoplankton. Mar. Ecol. Progr. Ser. 77, 183-196.

Xu, J., Yin, K., Liu, H., Lee, J.H.W., Anderson, D.M., Ho, A.Y.T., Harrison, P.J., 2010. A comparison of eutrophication impacts in two harbours in Hong Kong with different hydrodynamics. J. Mar. Syst., GEOHAB Modeling 83, 276-286.

doi:10.1016/j.jmarsys.2010.04.002

Yamamoto, T., 2003. The Seto Inland Sea-eutrophic or oligotrophic? Mar. Pollut. Bull. 47, 37-42. doi:10.1016/S0025-326X(02)00416-2

Zapata, M., Rodriguez, F., Garrido, J.L., 2000. Separation of chlorophylls and carotenoids from marine phytoplankton: a new HPLC method using a reversed phase C8 column and pyridine-containing mobile phases. Mar. Ecol. Prog. Ser. 195, 29-45.

doi:10.3354/meps 195029 


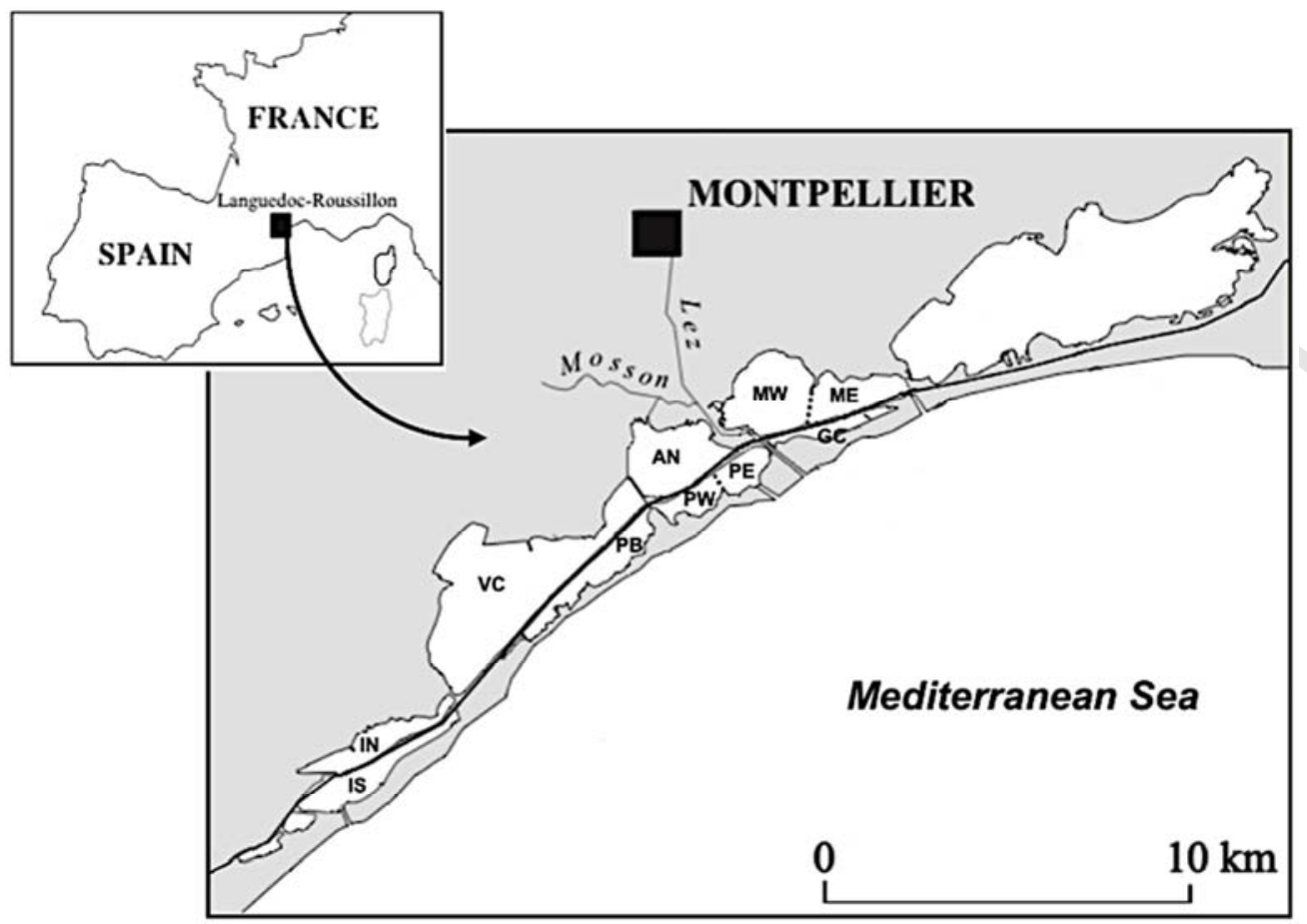

995 Figure 1: Location of the sampling stations, into the eight lagoons of the Palavasian complex, 996 next to the Montpellier city agglomeration. The dark line is represents the Rhône-to-Sète 997 canal.

999 Table 1. Characteristics of the 10 stations of the 8 coastal lagoons from the Palavasian complex. Trophic status, freshwater inputs and seawater exchanges are specified, from

1001 Souchu et al., 2010 and Bec et al., 2011.

\begin{tabular}{|c|c|c|c|c|c|c|c|c|}
\hline Lagoon & $\begin{array}{l}\text { Trophic } \\
\text { status }\end{array}$ & $\begin{array}{l}\text { Area } \\
\left(\mathrm{km}^{2}\right)\end{array}$ & $\begin{array}{l}\text { Volume } \\
\left(10^{6} \mathrm{~m}^{3}\right)\end{array}$ & $\begin{array}{c}\text { Mean } \\
\text { depth } \\
(\mathrm{m})\end{array}$ & $\begin{array}{c}\text { Main } \\
\text { freshwater }\end{array}$ & $\begin{array}{l}\text { Connections } \\
\text { to the sea }\end{array}$ & Station & $\begin{array}{l}\text { Label } \\
\text { of the } \\
\text { Station }\end{array}$ \\
\hline Méjean & Hypertrophic & 5.5 & 4.1 & 0.75 & Channel & Indirect & $\begin{array}{l}\text { East Méjean } \\
\text { West Méjean }\end{array}$ & $\begin{array}{l}\text { ME } \\
\text { MW }\end{array}$ \\
\hline Grec & Hypertrophic & 2.7 & 0.7 & 0.30 & Channel & Indirect & Grec & GC \\
\hline Arnel & Hypertrophic & 4.7 & 1.9 & 0.40 & River & Indirect & Arnel & AN \\
\hline Prévost & Eutrophic & 3.8 & 2.9 & 0.75 & Channel & Direct & $\begin{array}{l}\text { East Prévost } \\
\text { West Prévost }\end{array}$ & $\begin{array}{l}\text { PE } \\
\text { PW }\end{array}$ \\
\hline Vic & Eutrophic & 11.5 & 13.8 & 1.2 & Channel & Indirect & Vic & $\mathrm{VC}$ \\
\hline $\begin{array}{l}\text { Pierre } \\
\text { blanche }\end{array}$ & Eutrophic & 3.7 & 1.5 & 0.4 & Channel & Indirect & $\begin{array}{l}\text { Pierre } \\
\text { blanche }\end{array}$ & PB \\
\hline $\begin{array}{l}\text { North } \\
\text { Ingril }\end{array}$ & Mesotrophic & 3.2 & 2.2 & 0.6 & Channel & Indirect & North Ingril & IN \\
\hline $\begin{array}{l}\text { South } \\
\text { Ingril }\end{array}$ & Mesotrophic & 3.6 & 1.9 & 0.6 & Channel & Direct & South Ingril & IS \\
\hline
\end{tabular}


1003 Table 2. Median values and ranges (minimum and maximum values between brackets) of 1004 salinity, temperature, chlorophyll $a$, total nitrogen and total phosphorus concentrations, during 1005 summer periods, from 2000 to 2013.

\begin{tabular}{cccccccc}
\hline Station & Salinity & $\begin{array}{c}\text { TN } \\
(\mu \mathrm{M})\end{array}$ & $\begin{array}{c}\mathrm{TP} \\
(\mu \mathrm{M})\end{array}$ & $\begin{array}{c}\text { Chl } a \\
\left(\mu \mathrm{gChl} a . \mathrm{L}^{-1}\right)\end{array}$ & $\begin{array}{c}\text { PE-CYAN } \\
\left(10^{6} \mathrm{cell} / \mathrm{L}^{-1}\right)\end{array}$ & $\begin{array}{c}\text { PEUK } \\
\left(10^{6} \mathrm{cell} / \mathrm{L}^{-1}\right)\end{array}$ & $\begin{array}{c}\text { NANO } \\
\left(10^{6} \mathrm{cell} / \mathrm{L}^{-1}\right)\end{array}$ \\
\hline MW & $26.8(13.9-38.1)$ & $196(42.7-527)$ & $12.4(2.8-30.0)$ & $83.1(1.6-413)$ & $0(0-267)$ & $1000(0-9158)$ & $6.9(0-16303)$ \\
ME & $30.0(19.9-36.5)$ & $108(37.6-296)$ & $5.6(1.2-17.7)$ & $42.2(0.7-274)$ & $1.3(0-333)$ & $280(0.5-4567)$ & $5.1(0-4300)$ \\
GC & $32.0(22.1-39.8)$ & $149(36.1-432)$ & $8.0(1.5-32.4)$ & $73.2(0.9-361)$ & $3.6(0-72.9)$ & $257(3.7-6526)$ & $13.1(0-455)$ \\
AN & $35.7(16.9-45.9)$ & $86.3(34.5-298)$ & $4.6(1.5-27.0)$ & $47.6(1.0-393)$ & $0.5(0-57)$ & $49.4(1.3-22000)$ & $7.6(0.8-1660)$ \\
PW & $36.8(27.1-44.0)$ & $56.0(25.4-137)$ & $2.4(0.7-6.1)$ & $12.7(0.7-54.0)$ & $1.2(0-18.9)$ & $10.4(0.2-1900)$ & $5.8(0.5-128)$ \\
PE & $36.5(30.7-40.5)$ & $53.0(15.4-188)$ & $2.3(0.8-8.8)$ & $15.2(0.8-104)$ & $2.7(0-79.4)$ & $32(0.4-725)$ & $10.5(0.2-627)$ \\
VC & $38.1(21.4-51.0)$ & $65.2(38.2-166)$ & $3.0(0.8-13.0)$ & $9.9(1.2-50.8)$ & $0(0-10.6)$ & $15.4(0.4-3200)$ & $3.5(0-63.4)$ \\
PB & $37.3(23.3-48.1)$ & $69.6(37.1-132)$ & $3.8(1.4-8.2)$ & $20.9(1.3-101)$ & $0.2(0-32)$ & $15.8(1-1975)$ & $4.3(0-157)$ \\
IN & $38.8(31.9-44.1)$ & $34.5(16.0-80.0)$ & $1.2(0.4-4.9)$ & $4.8(0.1-20.8)$ & $1.7(0-43)$ & $16.2(0.7-1081)$ & $2.3(0-18.6)$ \\
IS & $38.9(33.8-44.5)$ & $30.7(9.6-75.6)$ & $0.9(0.5-1.9)$ & $3.7(0.2-20.5)$ & $5(0-237)$ & $5(0-237)$ & $1.7(0-24.8)$ \\
\hline
\end{tabular}

1006 

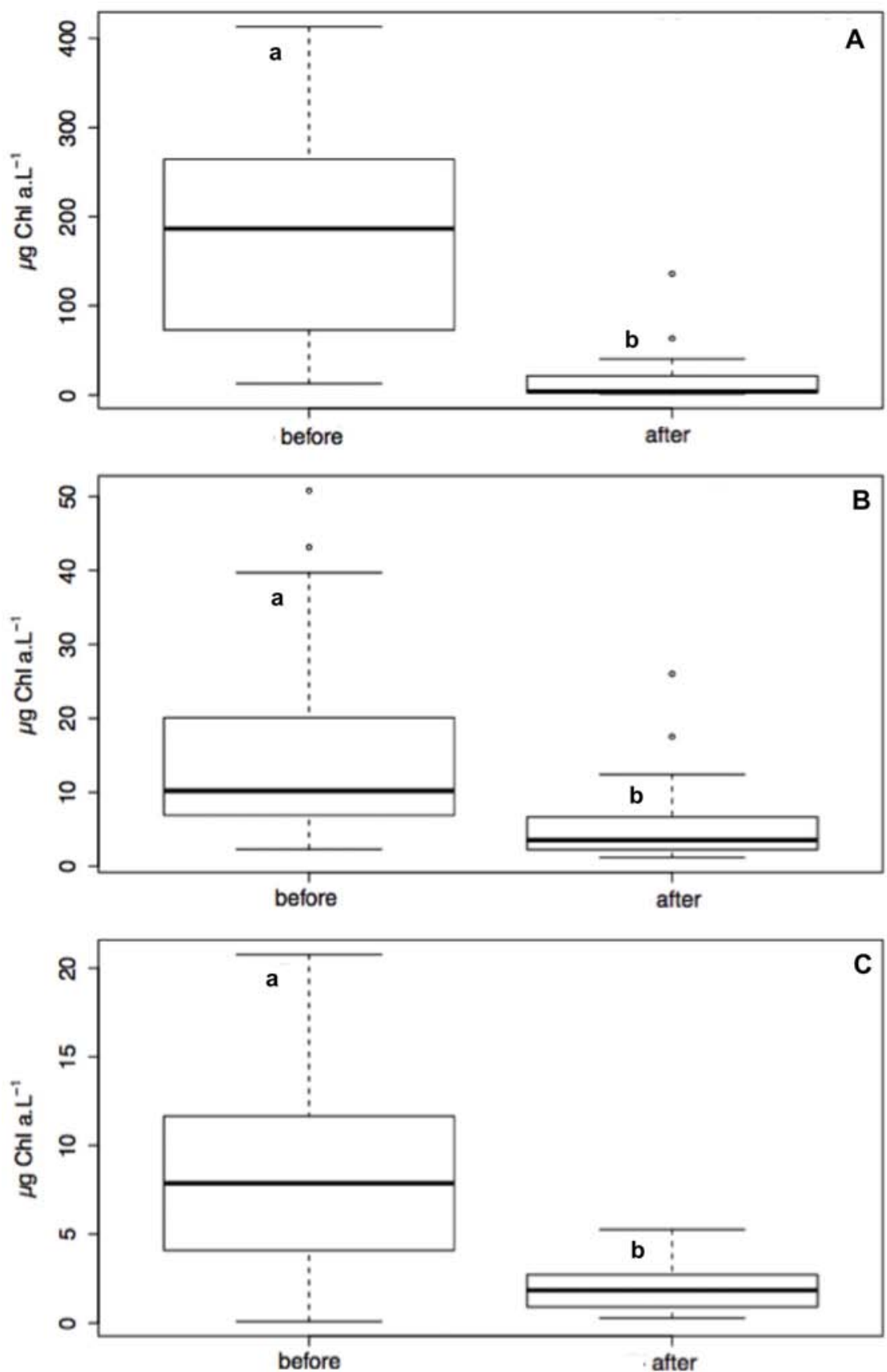

1009 Figure 2. Distributions of Chl $a$ concentration in hypertrophic (MW, A), eutrophic (VC, B) 1010 and mesotrophic (IN, C) lagoons. Box-and-whisker plots from summer values from 2000 to 10112005 (before diversion), and from 2006 to 2013 (after diversion). The whiskers represent the 1012 5th and the 95th percentiles, the outer edges of the boxes represent the 25th and 75th 1013 percentiles, and the horizontal line within the boxes represents the median. Significant 1014 difference between means before and after is illustrated by different letters ( $a$ and $b$ ). 

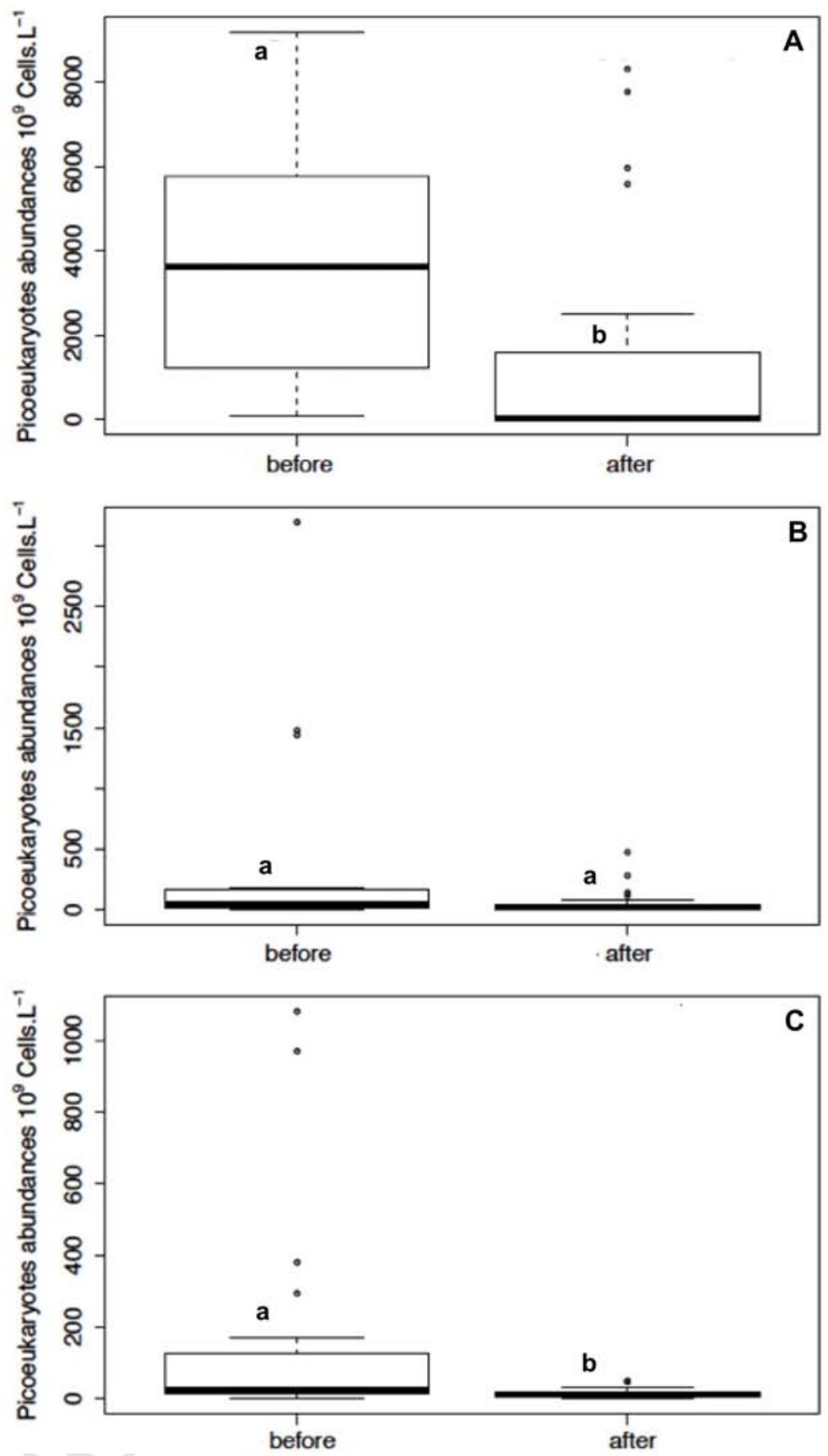

1018 Figure 3. Distributions of picoeukaryote abundances in hypertrophic (MW, A), eutrophic 1019 (VC, B) and mesotrophic (IN, C) lagoons. Box-and-whisker plots from summer values from 10202000 to 2005 (before diversion), and from 2006 to 2013 (after diversion). The whiskers 1021 represent the 5th and the 95th percentiles, the outer edges of the boxes represent the 25th and 1022 75th percentiles, and the horizontal line within the boxes represents the median. Significant 1023 difference between mean before and after is illustrated by different letters ( $a$ and $b$ ). 


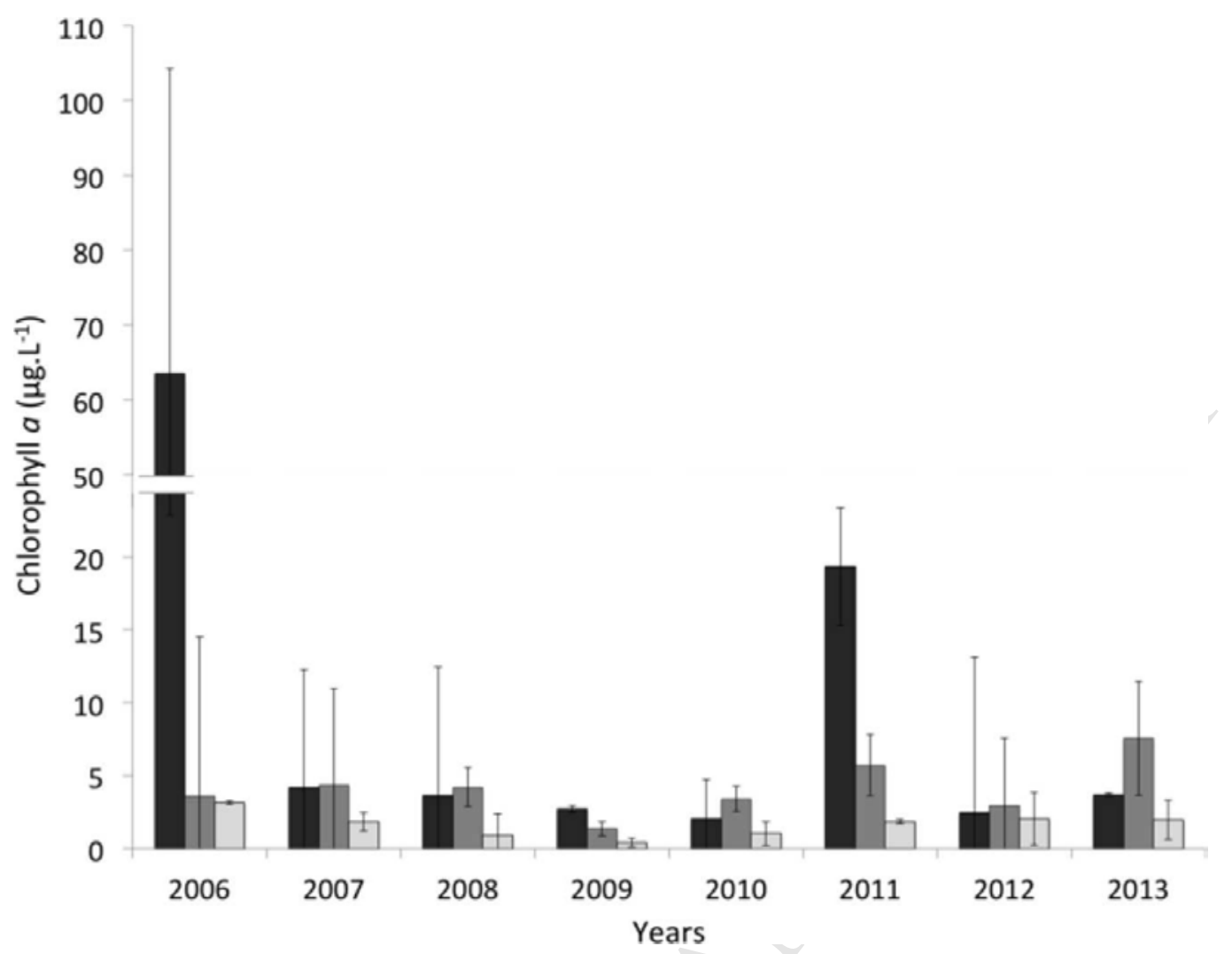

1026 Figure 4. Summer chlorophyll $a$ concentrations in hypertrophic (MW), eutrophic (VC) and 1027 mesotrophic (IN) lagoons from 2006 to 2013. Means of three summer values (June, July, 1028 August). Black, dark gray and light gray indicate MW, VC and IN lagoons, respectively. 
1030 Table 3. Summer concentrations of pigment markers of main phytoplanktonic groups in 2006

1031 in hypertrophic (MW), eutrophic (VC) and mesotrophic (IN) lagoons. Means of three summer 1032 values (June, July, August).

\begin{tabular}{lcccc}
\hline \multicolumn{1}{c}{ Pigments and associated taxonomic group } & MW & VC & IN \\
& \multicolumn{3}{c}{$\left(\mu \mathrm{g} . \mathrm{L}^{-1}\right)$} \\
\hline Fucoxanthin (diatoms) & 22.28 & 0.11 & 0.62 \\
Zeaxanthin (cyanobacteria - chlorophytes - prasinophytes) & 4.29 & 0.04 & 0.06 \\
Chlorophyll $b$ (green algae) & 1.73 & 0.16 & 0.1 \\
Lutein (chlorophytes - prasinophytes) & 3.06 & 0.07 & 0.06 \\
Neoxanthin (chlorophytes - prasinophytes) & 1.58 & 0.02 & 0.00 \\
Prasinoxanthin (prasinophytes) & 0.68 & 0.08 & 0.06 \\
Alloxanthin (cryptophytes) & 0.01 & 0.16 & 0.16 \\
19'But-fucoxanthin (haptophytes) & 0.04 & 0.00 & 0.00 \\
19'Hex-fucoxanthin (haptophytes) & 0.10 & 0.02 & 0.04 \\
Peridinin (dinophytes) & 0.05 & 3.87 & 0.16 \\
\hline
\end{tabular}

1033

1034

1035 


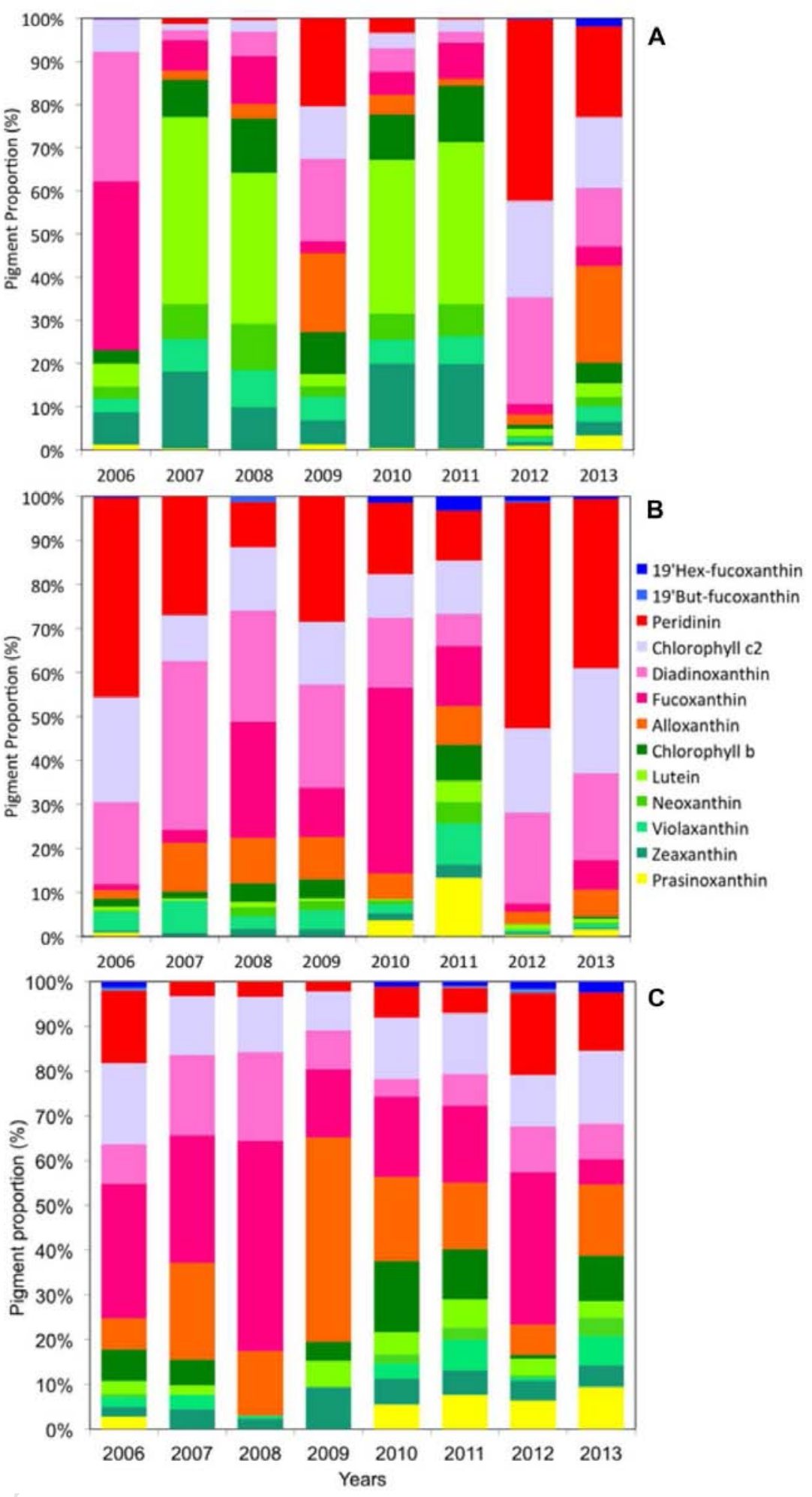

1037 Figure 5. Proportions of accessory pigments in hypertrophic (MW, A), eutrophic (VC, B) and 1038 mesotrophic (IN, C) lagoons from 2006 to 2013. Samplings were performed in June, July, 1039 August) and the data have been calculated from mean summer values for each year. 

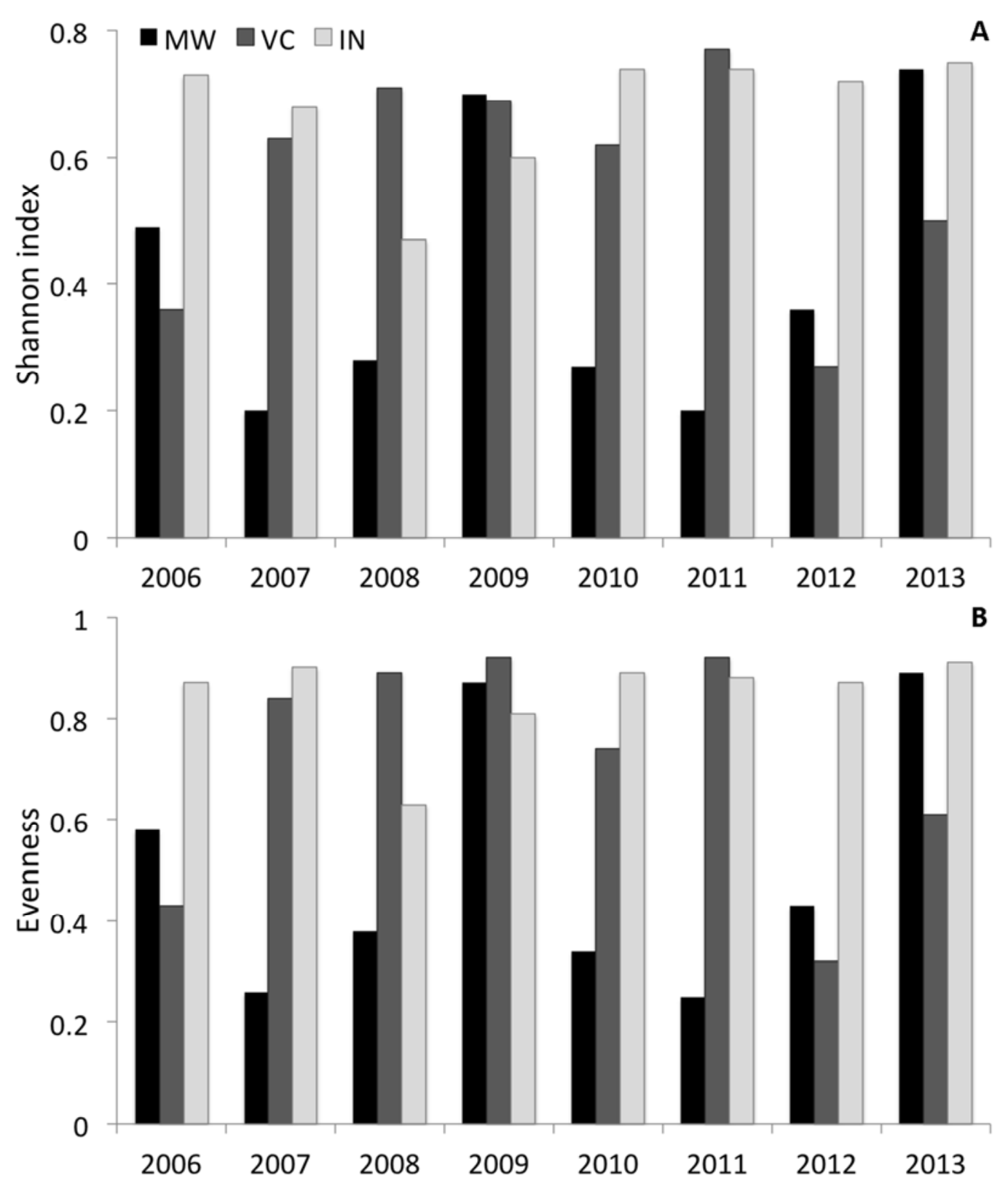

1043 Figure 6. Values of Shannon diversity Index (A) and Evenness (B) of the phytoplankton 1044 communities in hypertrophic (MW in black), eutrophic (VC in dark grey) and mesotrophic 1045 (IN in light grey) lagoons, based of the phytoplankton pigment composition during summer 1046 period (June, July, August) from 2006 to 2013. 


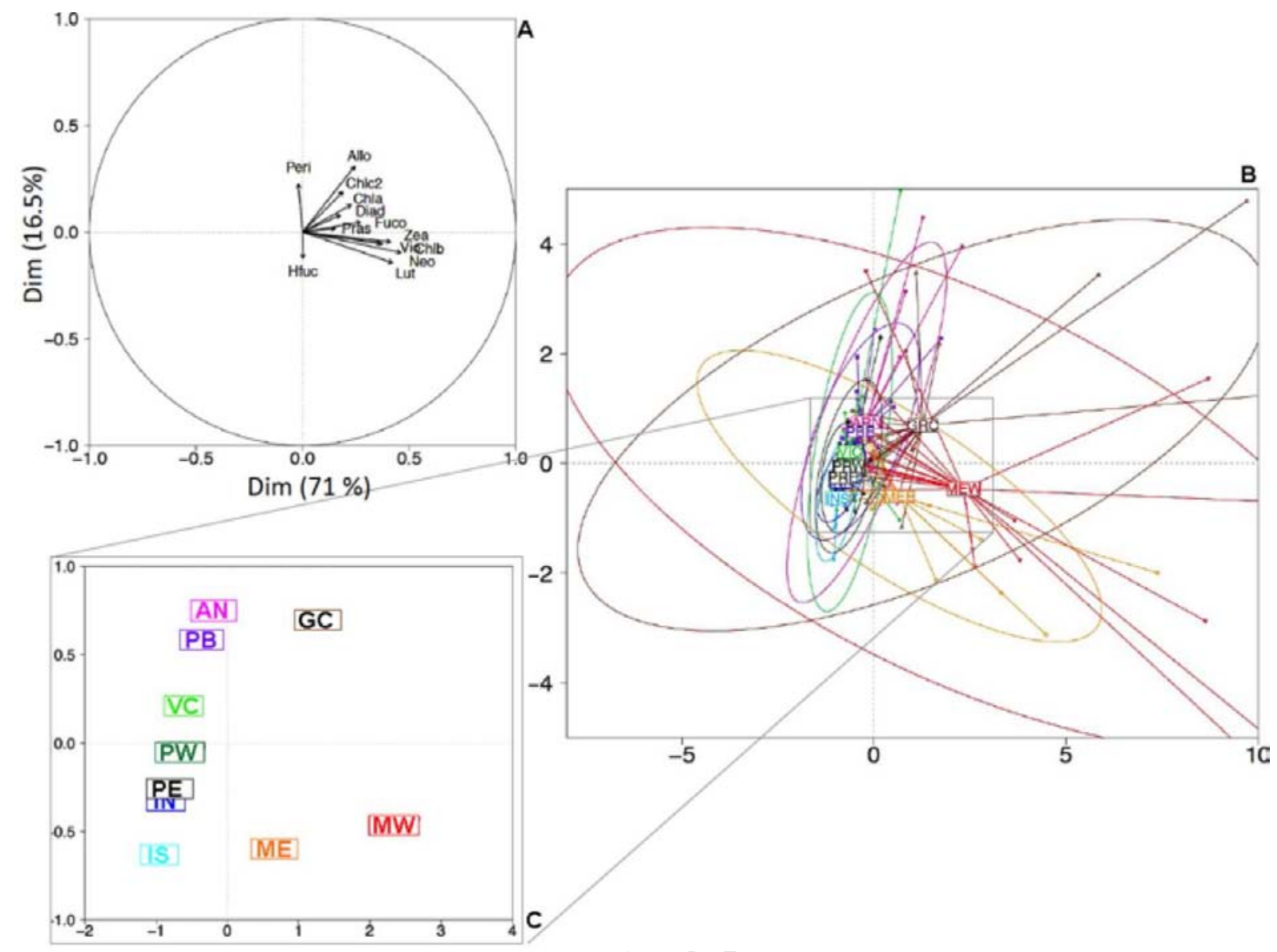

Figure 7. Between-class PCA by stations of the summer monitoring from 2006 to 2013 on the 105110 stations in the Palavasian complex. Correlation circle shows a projection of the pigment 1052 concentration along the two first axes with different percent of variance between-class. 1053 Arrows represent pigments (A) Projection of pigment composition of the ten stations for the 8 1054 years monitoring along the two axes by years, (B) Labels correspond to the center gravity of 1055 all the values, and ellipse represent $95 \%$ confidence limit of the mean, (C) Position of each 1056 center of gravity. 

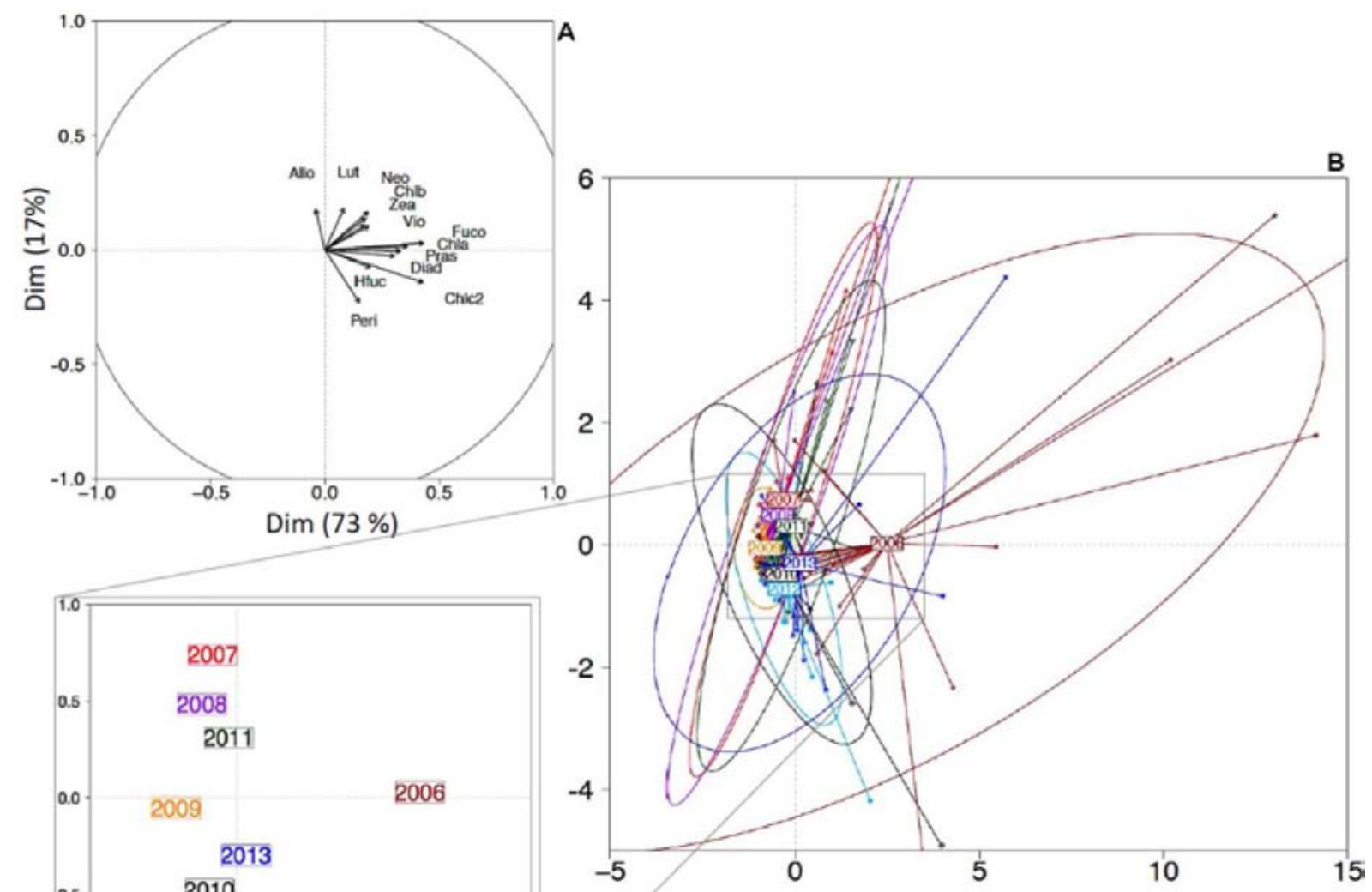

1059

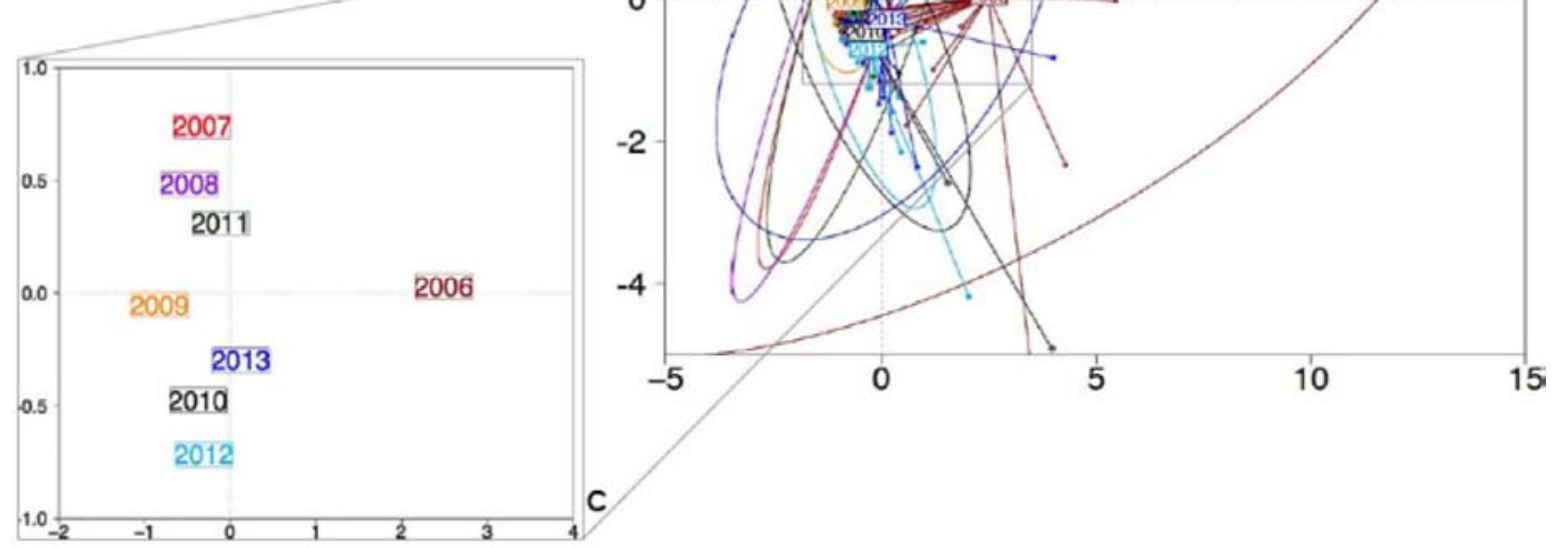

1060 Figure 8. Between-class PCA by years of the summer monitoring from 2006 to 2013 on the 106110 stations in the Palavasian complex. Correlation circle shows a projection of the pigment 1062 concentration along the two first axes with different percent of variance between-class. 1063 Arrows represent pigments (A) Projection of pigment composition of the ten stations for the 8 1064 years monitoring along the two axes by years, (B) Labels correspond to the barycenter of all 1065 the values, and ellipse represent 95\% confidence limit of the mean, (C) Position of each center of gravity. 


\section{Supplementary Materials}

1068

1069 Table S1. Statistics of mean comparison before and after the effluent diversion, of Chl $a$ $1070\left(\mu \mathrm{gChla} . \mathrm{L}^{-1}\right)$, total nitrogen and total phosphorus concentrations $(\mu \mathrm{M})$, with hypothesis $=$ 1071 concentration before > after (Wilcoxon test, R). Stars precise significance level (* p-value < $10720.05, * * \mathrm{p}$-value $<0.005, * * * \mathrm{p}$-value $<0.0005)$.

\begin{tabular}{cccc}
\hline Lagoons & TN & TP & Chl $a$ \\
\hline MW & $367 * * *$ & $359 * * *$ & $366 * * *$ \\
ME & $363 * * *$ & $351 * * *$ & $353 * * *$ \\
GC & $407 * * *$ & $405 * * *$ & $418 * * *$ \\
AN & $324 * * *$ & $318 * * *$ & $344 * * *$ \\
PW & $271.5 * * *$ & $274 * * *$ & $286 * * *$ \\
PE & $342.5 * * *$ & $324 * * *$ & $306 * * *$ \\
VC & $272 *$ & $295 * *$ & $298 * *$ \\
PB & $193 * * *$ & $183 * * *$ & $198 * * *$ \\
IN & $312 *$ & $350.5 * *$ & $383 * * *$ \\
IS & $267.5 *$ & $304 *$ & $376 * * *$ \\
\hline
\end{tabular}

1073 